\title{
Reducing aquatic micropollutants - Increasing the focus on input prevention and integrated emission management
}

\author{
Klaus Kümmerer a,b,*, Dionysios D. Dionysiou ${ }^{\mathrm{c}, \mathrm{d}}$, Oliver Olsson ${ }^{\mathrm{a}}$, Despo Fatta-Kassinos ${ }^{\mathrm{d}, \mathrm{e}}$ \\ a Institute of Sustainable and Environmental Chemistry, Leuphana University Lüneburg, Universitätsallee 1, 21335 Lüneburg, Germany \\ b International Sustainable Chemistry Collaboration Center (ISC ${ }_{3}$ ), Research and Education, Leuphana University Lüneburg, Universitätsallee 1, 21335 Lüneburg, Germany

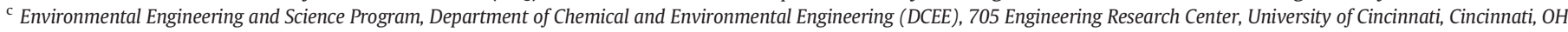 \\ 45221-0012, USA \\ ${ }^{d}$ Nireas-International Water Research Center, University of Cyprus, P.O. Box 20537, 1678, Nicosia, Cyprus \\ e Department of Civil and Environmental Engineering, University of Cyprus, P.O. Box 20537, 1678, Nicosia, Cyprus
}

\section{G R A P H I C A L A B S T R A C T}

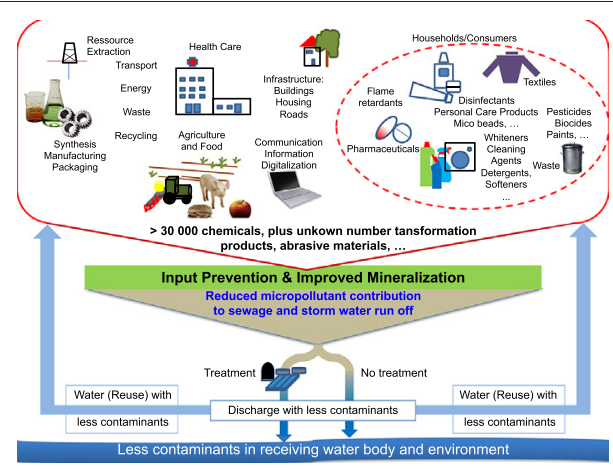

\section{A R T I C L E I N F O}

\section{Article history:}

Received 24 November 2016

Received in revised form 15 October 2018

Accepted 15 October 2018

Available online 17 October 2018

Editor: Damia Barcelo

\section{Keywords:}

Micro pollutant

Treatment

Prevention

Water

Sustainable development goal

Source

Sustainable chemistry

\begin{abstract}
A B S T R A C T
Pharmaceuticals and many other chemicals are an important basis for nearly all sectors including for example, food and agriculture, medicine, plastics, electronics, transport, communication, and many other products used nowadays. This comes along with a tremendous chemicalization of the globe, including ubiquitous presence of products of chemical and pharmaceutical industries in the aquatic environment. Use of these products will increase with population growth and living standard as will the need for clean water. In addition, climate change will exacerbate availability of water in sufficient quantity and quality. Since its implementation, conventional wastewater treatment has increasingly contributed to environmental protection and health of humans. However, with the increasing pollution of water by chemicals, conventional treatment turned out to be insufficient. It was also found that advanced effluent treatment methods such as extended filtration, the sorption to activated charcoal or advanced oxidation methods have their own limitations. These are, for example, increased demand for energy and hazardous chemicals, incomplete or even no removal of pollutants, the generation of unwanted products from parent compounds (transformation products, TPs) of often-unknown chemical structure, fate and toxicity. In many countries, effluent treatment is available only rarely if at all let alone advanced treatment. The past should teach us, that focusing only on technological approaches is not constructive for a sustainable water quality control. Therefore, in addition to conventional and advanced treatment optimization more emphasis on input prevention is urgently needed, including more and better control of what is present in the source
\end{abstract}

\footnotetext{
* Corresponding author at: Institute of Sustainable and Environmental Chemistry, Leuphana University Lüneburg, Universitätsallee 1, 21335 Lüneburg, Germany.

E-mail address: Klaus.Kuemmerer@uni.leuphana.de (K. Kümmerer).
} 
water. Measures for input prevention are known for long. The main focus though has always been on the treatment, and measures taken at the source have gained only little attention so far. A more effective and efficient approach, however, would be to avoid pollution at the source, which would in turn allow more targeted treatment to meet treated water quality objectives globally. New developments within green and sustainable chemistry are offering new approaches that allow for input prevention and a more targeted treatment to succeed in pollution elimination in and at the source. To put this into practice, engineers, water scientists and chemists as well as microbiologists and scientists of other related disciplines need to cooperate more extensively than in the past. Applying principles such as the precautionary principle, or keeping water flows separate where possible will add to this. This implies not minimizing the efforts to improve wastewater treatment but to design effluents and chemicals in such a way that treatment systems and water environments can cope successfully with the challenge of micropollutants globally (Kümmerer et al., 2018).

This paper therefore presents in its first part some of the limitations of effluent treatment in order to demonstrate the urgent need for minimizing water pollution at the source and, information on why source management is urgently needed to improve water quality and stimulate discussions how to protect water resources on a global level. Some principles of green and sustainable chemistry as well as other approaches, which are part of source management, are presented in the second part in order to stimulate discussion.

(C) 2018 Elsevier B.V. All rights reserved.

\section{Introduction}

Chemicals are indispensable, for example for health, food, and industrial production, and to maintain our standard of living but also for ecosystems. Constituents of consumer and technical products are introduced by intended use and as an unintended consequence of their use into the environment because of their application. In addition, auxiliary chemicals applied in production and manufacturing, as well as in resource extraction and recycling, can reach the aquatic environment unintentionally. This results in very complex, often unknown mixtures of chemicals of different nature, fate and activity in the water environment. In other words, the globally increasing chemicalization comes along with increasing pollution of the environment including the aquatic cycle. This includes also products of these chemicals formed in treatment or the aquatic environment (transformation products, TPs). In addition to the up-to-now more intensively studied organic and conventional inorganic chemicals such as ammonia, nitrate, and phosphate present at low levels in the aquatic environment (micropollutants, MPs), metal organic compounds, organic and inorganic nanoparticles and other chemically mixed materials, as well as hybrids e.g. with an inorganic core that carries organic functionalities, are increasingly used. Nowadays, almost the complete periodic table of elements is present in the production and use of consumer goods and technical products (Achzet et al., 2011); as long as they are not radioactive (with some exemptions for very limited use). At the same time manufacturers are trying to improve the stability of chemicals and pharmaceuticals to allow for longer storage at the shelf or stability in products, leading to increased persistence in the treatment process and the aquatic environment. Chemicals, products and materials are becoming more and more complex with increasingly new properties as possible by new methods and pathways of synthesis as well as new properties that may promise advantages or new products for the market. This translates into additional environmental fate and effects issues, at present and in the future too.

Wastewater treatment has increasingly reduced the presence of chemicals in the aquatic environment in the past. However, limitations are increasingly visible e.g. as the presence of chemicals is increasing in the aquatic cycle and the environment. Despite the high standard of effluent treatment in many European countries only "around $40 \%$ of surface waters are in good ecological status or potential, and only $38 \%$ are in good chemical status" according to a very recent report of the European Environment Agency (EEA, 2018). The report also says "If the widespread pollution by ubiquitous priority substances, including mercury, is omitted, the proportion of water bodies in good chemical status increases to $81 \%$. The main reasons for failure to achieve good status are ... (among others, added by the authors) discharges from urban wastewater treatment plants." (EEA, 2018). However, many of the within recent years newly detected chemical entities such as pharmaceuticals, artificial sweeteners, nanoparticles etc. and their transformation products are not included in this assessment because concentrations are below the respective environmental quality standard (EQS). Often EQS are not available and therefore many pollutants are not part of the assessment of the quality of European waters. One reason is the "historical" focus on bioaccumulative and legacy chemicals, which are most often chemicals of low polarity. That already demonstrates one of the challenges coming along with the everincreasing number of chemicals used. However, the EEA report states "Improved efforts to reduce these chemicals in wastewater treatment plants by improving treatment should go hand in hand with clear efforts to reduce them at source by raising consumer awareness and adjusting consumption, as well as through longer term initiatives". It is worth mentioning that this was emphasized by the EC (2015) already: "Member States should tackle the sources of pollution ... This is much preferable to using end-of-pipe treatment ... while avoiding high treatment costs and protecting the environment." (EU, 2015).

According to a United Nations (UN) report over $80 \%$ of the wastewater generated globally is released to the environment without treatment, let alone advanced treatment (UN Water, 2017). In some countries it is even more than 95\%. However, direct discharge of untreated municipal wastewater to adjacent water bodies takes also place in high-income countries, e.g. by combined sewer overflows and leakage of sewers. In 2008, it was reported that about $20 \%$ of public sewers and up to $50 \%$ of private sewers are leaking (Wagner, 2008). A study commissioned by the US Environmental Protection Agency reports between 14 and $50 \%$ leakage of sewers at different locations (Amic and Burgess, 2000). Furthermore, urban storm water containing compounds like metals, particles from industrial and traffic emissions (e.g. tires) and heating, biocides washed off from external thermal insulated composite systems of buildings (Burkhardt et al., 2007, Hensen et al., 2018) is often not treated and is released to urban aquatic environment. Veterinary pharmaceuticals from treated animals' excretions applied as fertilizer, plastic particles, pesticides, and other chemicals and their transformation products are released from agricultural lands into ground water or surface water too.

In other words, the increasing pollution of the aquatic cycle by MPs, challenges the availability of water as a source for drinking water, for industrial production (e.g. pharmaceuticals, electronics which need often ultrapure water) and food production in sufficient quantity and quality everywhere. The limitations of conventional wastewater treatment that is widely accepted nowadays urge us to potentially consider new integrated approaches to better protect water resources and to safeguard the availability of clean water on a global level in the long run. Although the discussion on input prevention and source control is not new, the nearly exclusive focus on measures for control pollution at the end 
during the last decades resulted in neglecting the root sources of the problem. Even though information on quantities of pollutants entering the aquatic environment, especially the origin of the active ingredients of pharmaceuticals is increasingly available (e.g. Herrmann et al., 2016a; Wieck et al., 2018), only few efforts were taken on preventive measures (Daughton, 2014). These are still not well established.

To fully understand and to underline the urgency of measures at the source we describe in the first part of this discussion paper the current situation related to the pollutant sources and their contributions to effluents as well as to the current achievements and limitations of conventional and advanced wastewater treatment technologies. Based on the fact that already several thousands of different parent substances are considered to be environmentally relevant, we further discuss the difficult task of a full risk assessment, which is needed for prioritization of treatment options at the various places and circumstances, and of the impact of even many more products suffering incomplete removal, degradation or transformation within treatment at the end of the pipe.

On the other hand, there is often only little knowledge outside the industrial environment why, where, and to which extent chemicals are used or are present in products (Wieck et al., 2016). Information on product ingredients are often difficult to get. In addition, this is hampered by chemicals having different trivial names but being identical. Furthermore, environmental properties still are often integrated only late or not at all in the development of new products instead from the very beginning. That is another challenge for a targeted treatment that is adapted and optimized for specific wastewater constituents. Therefore, in the second part of this paper, we place emphasis on pollutant input prevention and thus, on more control of what is present in the water of the source and its properties. This includes sustainable longterm local, regional and global strategies. In recent years, there have also been new developments in other sectors such as green as well as sustainable chemistry (Anastas and Warner, 1998; Kümmerer and Clark, 2016; Kümmerer, 2017) that can offer new measures at the source too.

\section{Increasing demand for clean water}

The quality of water is crucial for health, economic growth, food production, and the environment. Around $80-85 \%$ of the world population, i.e. approximately 5 billion people, lives in countries of low and middleincome. Among other threats, this population experiences a shortage of clean and safe water (OECD, 2012). In populous regions there are many freshwater aquifers already being contaminated and overdrawn. Because of the increasing population and standard of living, there will be an increased need of water of sufficient quality in many regions. Climate change is expected to exacerbate water quality, availability and need at the same time. In the coming decades water problems are expected to become worse, also in regions that are currently considered waterrich (Shannon et al., 2008). The Sustainable Development Goal \#6 of the UN emphasizes the need for water of sufficient hygienic and chemical quality in sufficient amounts (UN, 2015) for drinking, but also its use and reuse for personal hygiene, production and processing of food and in agriculture as well as in high technology sectors. However, the reuse of treated wastewater is increasingly endangered by chemical pollution.

As a means to address the growing water scarcity non-potable use of treated wastewater is increasing worldwide (Fatta-Kassinos et al., 2016; Maimon et al., 2014). Water reuse is attractive where no sufficient freshwater resources are available locally or the water supply depends on imported water. Even reuse of wastewater for drinking water purposes after extensive treatment is recently under discussion. Advanced extensive treatment currently is linked to a high specific energy need. Furthermore additional chemicals may be needed including proper facilities to store and apply them. This allows such approaches only in certain wealthy countries or regions such as Singapore and California (Drewes and Horstmeyer, 2016). Summarizing, "as the overall demand for water grows, the quantity of wastewater produced and its overall pollution load are continuously increasing worldwide" (UN Water, 2017).

\section{Increasing volume and diversity of chemicals}

More than 85,000 chemicals are marketed in the United States of America (Erickson, 2017). 100,000-140,000 chemicals that are marketed worldwide (UNEP, 2013; UBA, 2018) and new chemicals are also introduced into commerce each year. It is estimated 10,000 to 30,000 of the marketed chemicals are of relevance for the environment. In addition, about 3000 active pharmaceutical ingredients (APIs) are marketed. Most of them are relevant for the environment as they are most often incompletely metabolized and excreted. Most of the APIs and adjuvants of pharmaceuticals and the chemicals data relevant for environmental fate and effects are incomplete or not even available.

Both, their number (i.e. diversity, Fig. 1) and their volume (Fig. 2) will increase. According to the U.S. Environmental Protection Agency (U.S. EPA) an average of about 700 new chemicals are added per year to the Toxic Substances Control Act (TSCA) inventory (UNEP, 2013). This will result in a further chemicalization of the globe including ubiquitous presence of chemicals and pharmaceuticals in the water cycle. Changes of compounds and materials used can occur within a few years adding to the dynamics. An example demonstrating this is displayed in Fig. 3.

The chemicals, materials, and products can be classified according to the function they offer such as flame retardant (e.g. in textiles or plastics, Weil and Levchik, 2015), plasticizer, UV-screen, biocide, pesticide, surfactant, dye, anti-corrosive, chelating agent, softener, preservative, catalyst to mention only a few. Others are summarized according to the (un)wanted effects such as endocrine active compounds, mutagenic compounds, pharmaceuticals etc. Many are present in not just one but several or even many products. Most often these groups consist of a high number of very different compounds with different properties. For example, the group of antibiotics consists of approximately 250 different compounds that again can be classified by chemical subgroups of different chemical structure, properties and activity such as $\beta$-lactams, aminoglycosides, fluoroquinolones and many others. Within the $\beta$ lactams there are subgroups such as penicillins and cephalosporins, encompassing in total more than 40 different individual molecules (Frank and Taconelli, 2012). There are more than one hundred different APIs of anti-cancer drugs (BC Cancer, 2018). They are most often grouped according to their mechanism of action, which goes along with different risk, and again consisting of subgroups of chemically highly diverse APIs even within subgroups (Kümmerer, 2010. The number of food additives detected in the environment is also increasing,

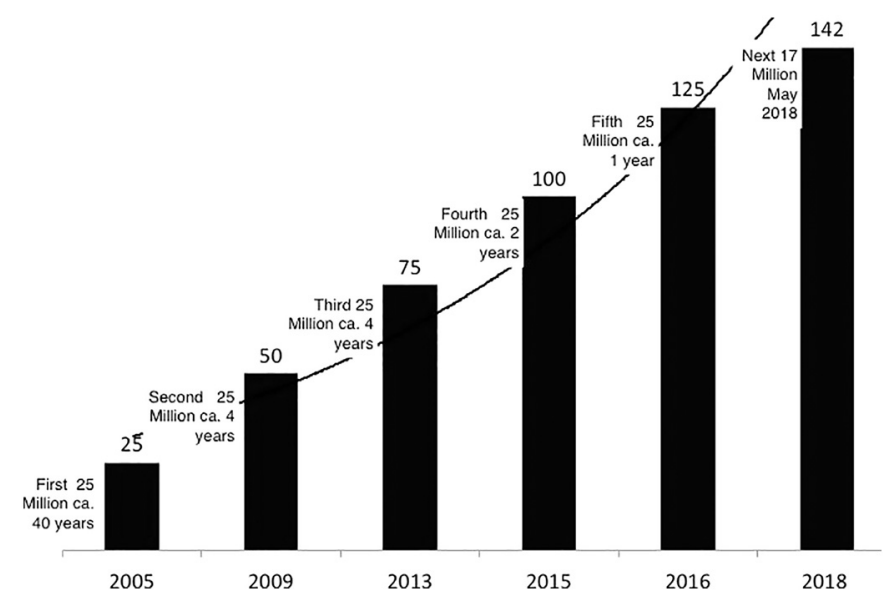

Fig. 1. Past increase of number of chemicals registered in CAS registry (data source www cas.org). 


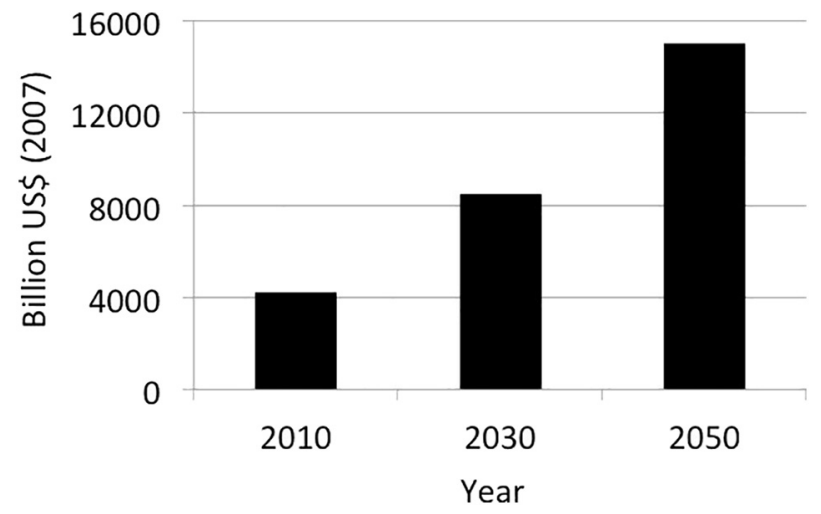

Fig. 2. Sales value of chemicals. (Data source: OECD, 2012).

albeit only for a few such as artificial sweeteners at least some knowledge is emerging. The situation is more or less similar for other chemicals. Pesticides include approximately 800 individual active compounds (Greene and Pohanish, 2005) from various chemical families such as organochlorines, organophosphates, and carbamates with various subgroups such as organochlorine hydrocarbons which could further be divided in dichlorodiphenylethanes (e.g., DDT), cyclodienes such as aldrine or dieldrine, and other related compounds including other subclasses such as thiocarbamates and dithiocarbamates. Again other groups of pesticides are benzoic and phenoxy acid herbicides (e.g. 2,4-D), triazines (e.g., atrazine), ureas (e.g., diuron), and chloroacetanilides (e.g., alachlor), neonicotinoids (e.g. imidachloprid) to mention just a few.

Other examples of chemically highly diverse product groups include personal care products or flame retardants, again consisting of different chemical subgroups (Bester, 2007). Another group is dyes used in textile, paper and printing industries. Dyes also comprise more than 10 big subgroups including many compounds. For the production of textiles about 5000 auxiliary products based on 400-600 active components are listed (TEGEWA, 2018). Again all of them differ in chemical structure and properties such as reactivity, water solubility and others. Another example is fracturing chemicals (https://fracfocus.org/ chemical-use/what-chemicals-are-used). Additionally, medications and many products such as pesticides contain also adjuvants and excipients (Wirz et al., 2015; Gutowski et al., 2015), which modulate their environmental fate and activity. This is most often not in focus. Many other groups of chemicals such as organo silicones that are often used as adjuvants also consist of many different compounds (Rücker and Kümmerer, 2015). These and others such as flame-retardants, chlorinated hydrocarbons, per- or highly fluorinated hydrocarbons and acids or surfactants often consist of mixtures of many compounds within subgroups such as homologues and isomers (i.e. congeners) let alone the increasing number of nanoparticles (organic, inorganic, surface coated). The extremely persistent per- and polyfluorinated alkyl substances (PFAS), for example comprise about 3000 different individual compounds within at least seven subgroups (Stahl et al., 2017; $\mathrm{EU}, 2017$ ) that are found in cosmetics, food contact materials, inks, medical devices, mobile phones, and textiles, and are used in pesticide formulations, oil production and mining (EU, 2017). Ionic liquids have been seen as the green solvents of the future. However, often they are not environmentally biodegradable and are toxic to aquatic organisms. At the same time, they are increasingly used outside chemical synthesis such as gas, coal, and nuclear fuel processing. They are also used within new technologies that will be decisive for a sustainable development such as solar thermal energy systems, cellulose processing, waste recycling, batteries, and carbon capture. They may therefore increasingly enter the aquatic environment in the future.

A common challenge even for chemists is that organic chemicals often have multiple names, which makes it difficult to allocate them to products after they have been detected in the environment.

Due to their use, rare earth metals are increasingly present in the aquatic environment too, but relevant knowledge on their environmental behavior, fate and effects of these increasingly used metal organic compounds is scarce (Kümmerer and Helmers, 2000; Kulaksız and Bau, 2011; Hatje et al., 2016; Martino et al., 2017). Some tin organic compounds and mercury, including methyl mercury, are a rare exemption in this respect (Chung and $\mathrm{Wu}, 2017$ ).

In addition, TPs result from (bio)chemical transformation of chemicals within the technical systems but also after their release into the environment. Typical chemical reactions are oxidation, reduction or hydrolysis facilitated by metabolism of organisms, light, heat, $\mathrm{pH}$ etc. (Fatta-Kassinos et al., 2010). In case of metals and other elements and inorganic compounds the transformation relates to a change in the oxidation state, which translates to a change in fate and toxicity. The same holds for most of the TPs resulting from organic compounds. However, in this case most often TPs are not known. Products and materials consisting of different components and building blocks such as plastics and other polymers like polysiloxanes, for example, disintegrate during use or while in the environment at the end of their life (Capela et al., 2016; Rücker and Kümmerer, 2015) releasing constituents such as additives and other follow up TPs and materials such as (nano)

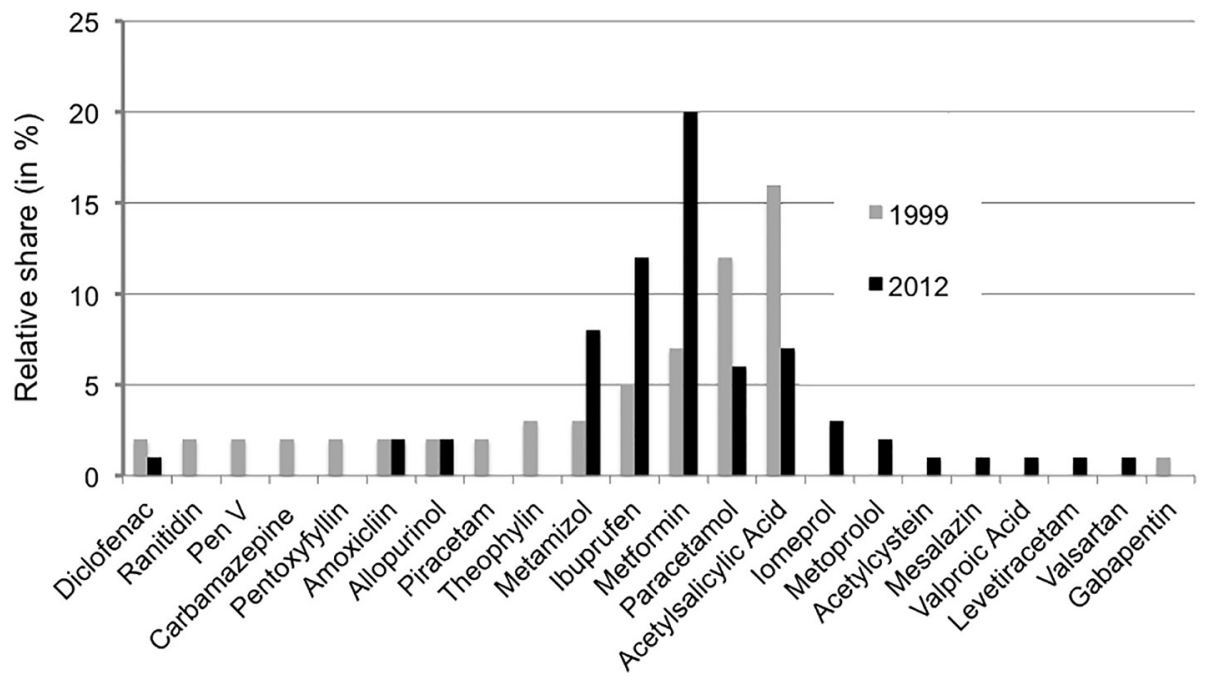

Fig. 3. Relative share (in \%) of different active ingredients in pharmaceuticals in Germany in different years. (Data source: Ebert et al., 2014). 
particles. The same can be assumed for inorganic composite materials albeit knowledge is very little.

What do we have to expect for the future? The huge increase in the production volume of chemicals and chemical products; including plastics as the latest most prominent example; and their detection everywhere in the environment is seen as one of the markers of the Anthropocene (Waters et al., 2016; Rastogi et al., 2018). Bernhardt et al. (2017) demonstrated that synthetic chemicals are "increasing as or more rapidly than other agents and indicators of global change related to their total quantity, diversity, and geographic expansion". This development will continue and will intensify in the future economic growth, population growth, increasing age and living standard will be drivers too and will cause a further growth of the production volume and usage of chemicals, materials, chemical products, and pharmaceuticals worldwide. According to progress in pharmacy and chemistry the diversity of organic, inorganic molecules, materials, and products used will increase globally also to meet the SDGs.

Advanced technology metals (e.g. from rare earth group, platinum group) as well as metalloids such as gallium, indium, germanium and others for products for the turnaround in energy policy, mobility (e.g. electric and autonomous cars), modern communication devices or medical applications as well as in production including synthetic fuels (e.g. chemical catalysis) will increasingly be used. Other increasingly used metals are lithium, cobalt or beryllium. Often the metals are widely dissipated not just with increasing number of production centers but also with products and their use. For example, it is expected that humans suffering from diabetes will increase from 387 million today to 592 million in 2035 (DeLoitte, 2016). The quick change of compounds used (Fig. 3), most often results in the fact that the compounds of the past are often extensively studied whereas the compounds only recently introduced into the market and thereby into the environment or the ones just at the "gate" are not in focus and will be studied most often with a time gap (Kümmerer, 1996, Weiser et al., 2017) of several years only which is another "end of the pipe" feature. Interestingly, most of the issues Rachel Carson described in her seminal book "Silent Spring" already more than 50 years ago are still the same nowadays (Carson, 1962).

Summarizing, the global socio-economic developments of the last decades resulted in a steep increase of volume and diversity of chemicals and pharmaceuticals. As a result of their use more and more of their constituents will also emerge in the aquatic environment. This development will intensify in the future.

\section{Presence of chemicals in the aquatic environment}

A considerable share of the chemicals and pharmaceuticals is introduced into wastewater and the aquatic environment as a direct consequence of their regular use in households, craft, industry, healthcare, agriculture, buildings, traffic and other sectors. Other chemicals end up in aquatic systems as an unintended consequence of their use. Therefore, many chemicals are present more or less everywhere in the aquatic environment in the $\mu \mathrm{g} / \mathrm{L}$ range or even lower (Kümmerer, 2010; Schwarzenbach et al., 2006). This holds for parent compounds as well as for TPs. TPs and many pharmaceuticals are of considerable polarity and therefore highly mobile in the aquatic environment. Recent discussions therefore ask to subsume organic chemicals as a specific group which was not in focus up to now as the conventional approach of a high bioaccumulation potential as a filter for prioritization does not include them (Reemtsma et al., 2016). Therefore, such polar and highly mobile organic chemicals are called MPs and their presence is increasingly detected in a significant extent all over the world. In general, there are more and more MPs detected in the environment. A recent example among many is heterocyclic aromatic compounds (Siemers et al., 2015). Also rare earth metals can be considered emerging MPs. Their different species and compounds have not yet been addressed by the term MPs but already first indications exist for rare earth metals, e.g. gadolinium or dysprosium (Kulaksız and Bau, 2011, Kümmerer and Helmers, 2000, Möller et al., 2000). Gadolinium meanwhile is used as a lead substance marking anthropogenic influences. Many other chemicals have probably not been searched for or detected yet given the number used compared to the number analyzed. These unknowns are not yet in the focus of aquatic research.

All these chemical entities have different physical chemical as well as biological and toxic properties that translate to different accessibility for analysis, fate, effects and possible risks. After entering into the environment, they all may follow a different pathway as their fate depends on the $\mathrm{pH}$, sorption, volatility, and different stability, e.g. against light, hydrolysis, oxidation, reduction, and biodegradation in nature or in engineered treatment processes. Unwanted reaction products are formed through both abiotic and biotic processes are of different chemical structure than the parent compound. Kinetics of formation also differ depending on specific conditions and the individual chemical. Other factors that can be important for the pathway and the kinetics of the formation of TPs are the redox potential in the medium and of the compounds as well as accessibility to hydrolysis but also the presence of other compounds including dissolved organic matter (DOM), humic acids, extracellular polymeric substances (EPS) or inorganic anions that may act as photo sensitizers. In other words, there can be formed many different TPs depending on the individual circumstances. A high degree of uncertainty is often involved in the unambiguous establishment of the chemical structure of a hitherto unknown TP which translates directly to uncertainties in risk assessment (Menz et al., 2017) and advanced effluent treatment. TPs formed may not be detectable with chosen analytical methods or are formed at concentrations below the chosen instrument and method detection limits. Ionization rates in mass spectrometry depend on the compound and the chosen ionization method as within these constraints they depend on the matrix and accompanying material. Moreover, if there is a signal of certain intensity in the analysis that can be related to a TP this does not mean that its concentration is high and vice versa, since in most cases analysis of TPs cannot involve quantitative measurements due to lack of reference standards. It is questionable whether the analytical methods of the future such as non-target analysis will be able to fully solve this problem. This is because such analysis can only detect what was not lost during sampling and sample preparation. While it is believed that we know only a fraction of TPs, many known TPs which have recently been detected due to advances in analytical methods, consist of a variety of chemical structures and functionalities, and have different, often completely unknown, physicochemical properties compared to the parent compounds.

Summarizing, the presence of MPs in effluents and the aquatic environment results in a high complexity, which increases with every new chemical.

\section{The challenges of (an advanced) effluent treatment}

\subsection{The success story of treatment and its increasingly visible limits}

Besides disinfection and removal or at least reduction of pathogens, the removal of chemicals from wastewater and potable water represents undoubtedly a major technical progress within the last century that increased our life expectancy probably more than most other medical advancement. The various effective removal processes applied in conventional wastewater treatment such as mechanical treatment, activated sludge processes and clarification and in potable water treatment (i.e. filtration, adsorption to activated carbon, especially for surface water) have reduced the release of chemical substances into the aquatic environment. These also have resulted in higher quality potable water, respectively. Much effort is rightly directed to wastewater treatment for improving the reduction of the presence of bacteria and other microorganisms and chemicals in water. However, the diversity of already existing chemicals, the dynamics of usage of old and new chemicals as 
well as their anticipated increase is a huge challenge on its own for the successful prevention of their presence in the aquatic environment. That often results in calls for investment in the development and implementation of a certain (treatment) technology. This, however, results in a long-term fixing of the use of such a technology which therefore cannot be adapted as quickly as needed to react on new challenges such as e.g. new compounds which are often introduced shortly thereby making proper reaction on the new situation de facto impossible (Kümmerer, 1996; Weiser et al., 2017). Therefore, it is necessary to understand the advantages and disadvantages as well as the limitations of each approach.

\subsection{Conventional biological treatment and natural processes}

The low concentrations ( $\mu \mathrm{g} / \mathrm{L}$ range and below) of chemicals in (waste)water makes their removal challenging. The elimination rate of sorption onto the sewage sludge is often varying between chemicals and treatments, which is caused by the fact that different MPs also have different chemical properties and functional groups that can interact with a specific sorbent. Removal by sorption is often low for highly polar compounds such as pharmaceuticals and their metabolites or some of the already mentioned other chemicals and TPs.

Biological processes often result in a limited transformation of organic chemicals because of the resistance of many organic compounds to biodegradation. Bacterial enzymes often mediate formation of several different TPs within conventional treatment. Often a smaller number of TPs is formed via biotransformation compared to chemical oxidation in advanced treatment (see below) as enzymes are often substrate and product specific. Biodegradation kinetics and reaction products depend on the organisms that are involved and the nature of the chemical. Fungi possess enzymes that mediate $\mathrm{OH}$-radical driven biochemical processes of low selectivity. As a result, many TPs are formed. The removal rate also strongly dependents on the type and chemical structure of the compound (Falas et al., 2016; Funke et al., 2016; Gulde et al., 2016; Majewsky et al., 2015; Su et al., 2016; Trautwein et al., 2008). Even chemically closely related compounds can be of different biodegradability and can result in TPs of different persistence as has been demonstrated for the two chemically very similar $\beta$-lactam antibiotics amoxicillin and piperacillin (Längin et al., 2008).

Research has found that prolonged sludge age improves the removal rates of only a small number of MPs. In contrast, it might even create favorable conditions for the evolution of antibiotic resistance. Anaerobic treatment e.g. of sludge, indeed, can remove or even degrade some pollutants that are not removed by aerobic effluent treatment. However, it is long known that anaerobic treatment will also generate TPs. New trends in anaerobic biological processes for nutrient recovery have challenged the old approach (Jetten et al., 2001; Verstraete and Vlaeminck, 2011). Synthesis of useful chemicals in wastewater treatment plants has been brought forward as a new idea too (Jia et al., 2013, Luo et al., 2014, Mondala et al., 2012). It can be assumed that anaerobic treatment for nutrient recovery as well as for the generation of chemicals will be influenced by non-biodegradable MPs and possibly newly formed anaerobic TPs.

Summarizing, conventional effluent and potable water treatment processes cannot fully remove all the chemicals from wastewater as indicated by their presence in the aquatic environment.

\subsection{Advanced treatment}

In advanced treatment the removal percentages of the various MPs often also vary due to the varying structure and reactivity of MPs. Removal also depends on concentrations. It has been found that removal varies in combinations of treatment technologies too and may strongly depend on each contaminant. Even combinations of different (advanced) treatment processes do not remove entirely the pollutants and sometimes even only a minor share of them (Margot et al., 2013).

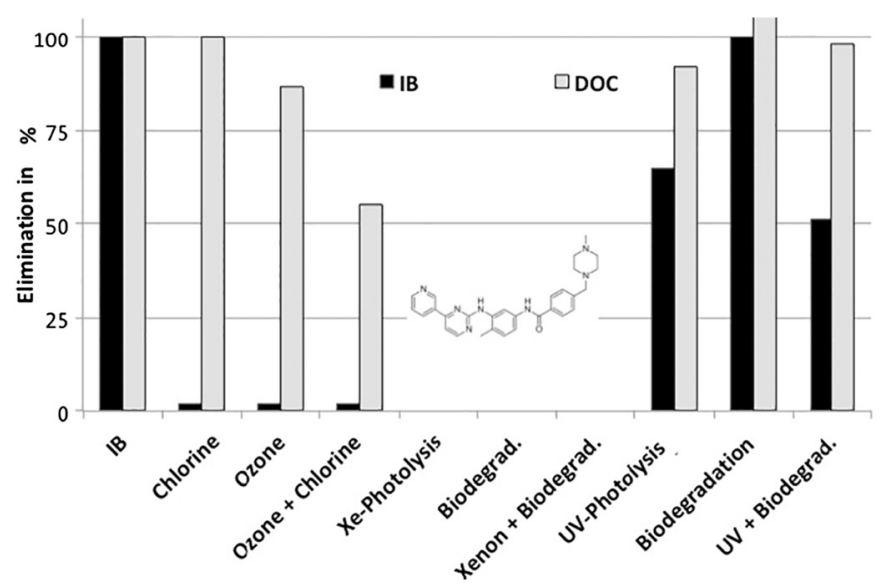

Fig. 4. Primary elimination of the anticancer drug imatinib (IB) by different treatments and degree of mineralization measured as dissolved organic carbon (DOC) (Haddad et al.; unpublished results, http://www.pharmas-eu.net/).

The individual removal rates within a certain treatment depend on treatment parameters, respectively (e.g. oxidant concentration, duration of treatment $\mathrm{pH}$, concomitant compounds). The amount and type present of dissolved organic carbon (DOC), which includes synthetic chemicals too, and natural organic matter (NOM), which includes suspended organic natural matter too, i.e. composition of the treated water are affecting removal and mineralization rates as well as number and type of TOPs formed (Kwon et al., 2015, Song et al., 2016, Lambropoulou and Nollet, 2014, Tootchi et al., 2013, Garcia-Käufer et al., 2012, Illes et al., 2014, López-Serna et al., 2013, Hanigan et al., 2015, Nödler et al., 2013, Antonopoulou and Konstantinou, 2016, Menz et al., 2017, Haddad and Kümmerer, 2014, Haddad et al., 2015, Amildon Ricardo et al., 2018, Zhang et al., 2018;). Accordingly, for many compounds many different transformations products are reported in literature. That is demonstrated in Figs. 4-6: Fig. 4 shows that the removal rate of a compound depends on the type of treatment. Fig. 5 demonstrates that the formation of many TPs from one parent compound within different treatments or under different treatment conditions is common. The high number and the dynamics of transformation products generated possibly even from a one compound within one specific treatment is exemplified by Fig. 6. Fig. 7 demonstrates how this relates to the dynamics of toxicity in that case and the significance of treatment time. The degree of removal and detoxification found depends on the endpoints monitored too (Nasuhoglu et al., 2018). Taken

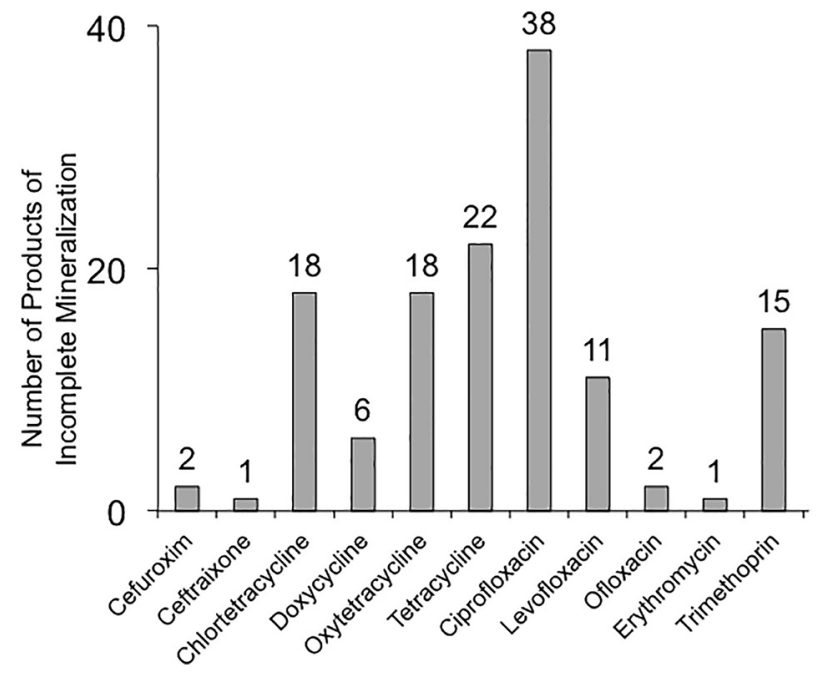

Fig. 5. TPs of different antibiotics reported in scientific literature until 2012. (Data from Haddad et al., 2015). 


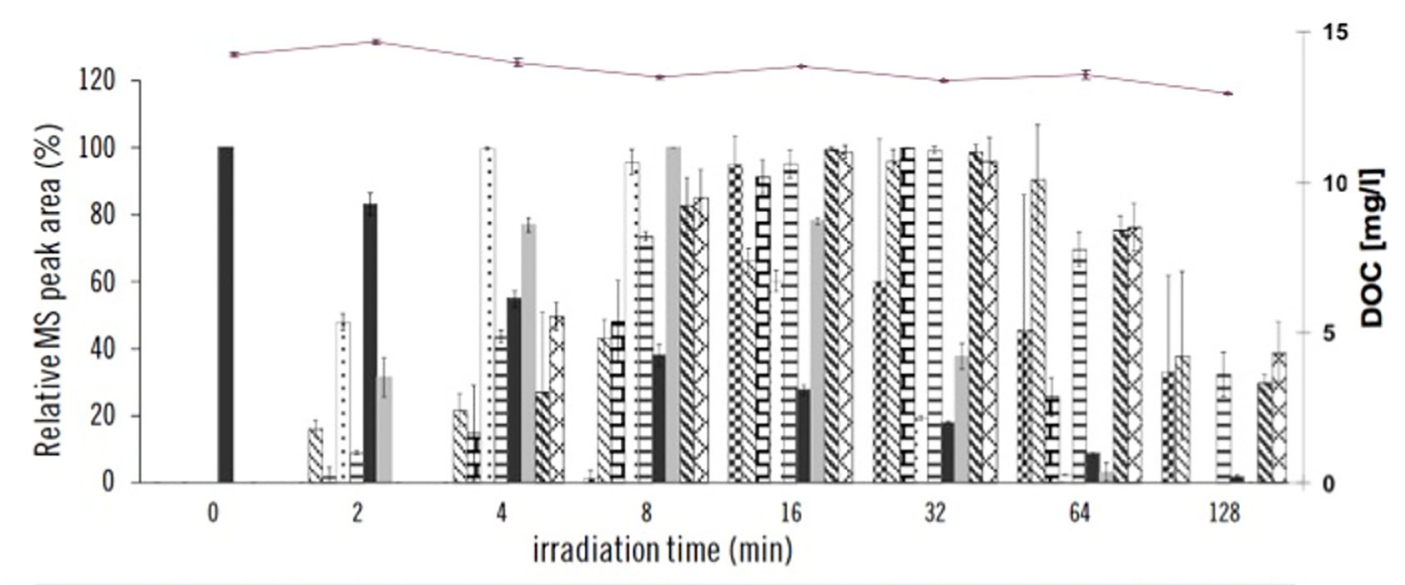

$\times 362.4(3.3) \otimes 362.4(4.4) \square 316.8(6.1)=330.3(6.3) \square 346.2(7.5)=332.2(8.0)=344.7(11.3) \mathrm{a} 316.3(11.7) \square 330.3(12.3)$

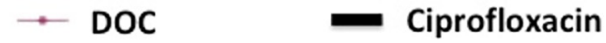

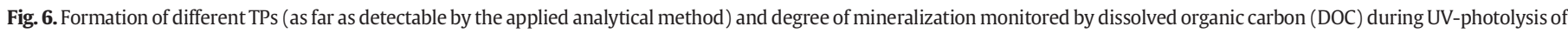
Ciprofloxacin (reprinted from Haddad and Kümmerer, 2014, with permission); $m / z$ : specific mass of TP, in brackets: retention time of TP.

together Figs. 4-7 demonstrate the complexity that comes along with the treatment of effluents that contain many different compounds and the challenge to select the right treatment technology, physical chemical conditions and treatment time for the complete mineralization of a given compound.

Adsorption can help removing some more hydrophobic compounds to minimize the presence of target contaminants before AOPs and other oxidation methods and thereby reducing formation of polar TPs. However, for some applications additional post-adsorption may be needed to remove TPs and reduce toxicity. Formation of more polar TPs by advanced oxidation treatment of non-polar target contaminants is the normal case. Adsorption to activated carbon is often low for some of them. Therefore, sorption of the target contaminants should precede the oxidative treatment. On the other hand, some TPs may be removed by filtering after advanced treatment anyway which would result in an even more complex setting of treatment. However, some more polar substances and TPs may adsorb better on the activated carbon if a biofilm is formed after a certain time, but less polar compounds will then adsorb to a lower degree. Currently no detailed knowledge on these kinds of processes and their benefits are available. In this context, further questions remain unexplored. Which effects have such biofilms on the potential evolution of resistance if the more polar antibiotics better adsorb on the activated carbon? We do not know. And what is the role of activated carbon as an adsorbent in the case of biofilm cultivation? How long is the lifetime and therefore the working activity of such biofilms? Application of membranes and other filtration technologies has shown to remove some groups of chemicals depending on the membrane and filter material and polarity of the chemical. Advantageously such a treatment does not result in TPs as adsorption does neither. However, the smaller the pore size the higher the energy demand, which is very high in case of reverse osmosis. Biofilm technology might have a potential for water treatment (El-Taliawy et al., 2018; Ooi et al., 2018). However, biofilm formation and deterioration ("fouling") of membranes is an often-reported issue, which decreases the lifetime and performance of membranes. Increased bacterial density (e.g. in biofilms) or increased sludge density may increase selection of antibiotic resistant bacteria as well as prolonged residence time of antibiotics in the treatment system. Slow-sand filters may be a good option too.

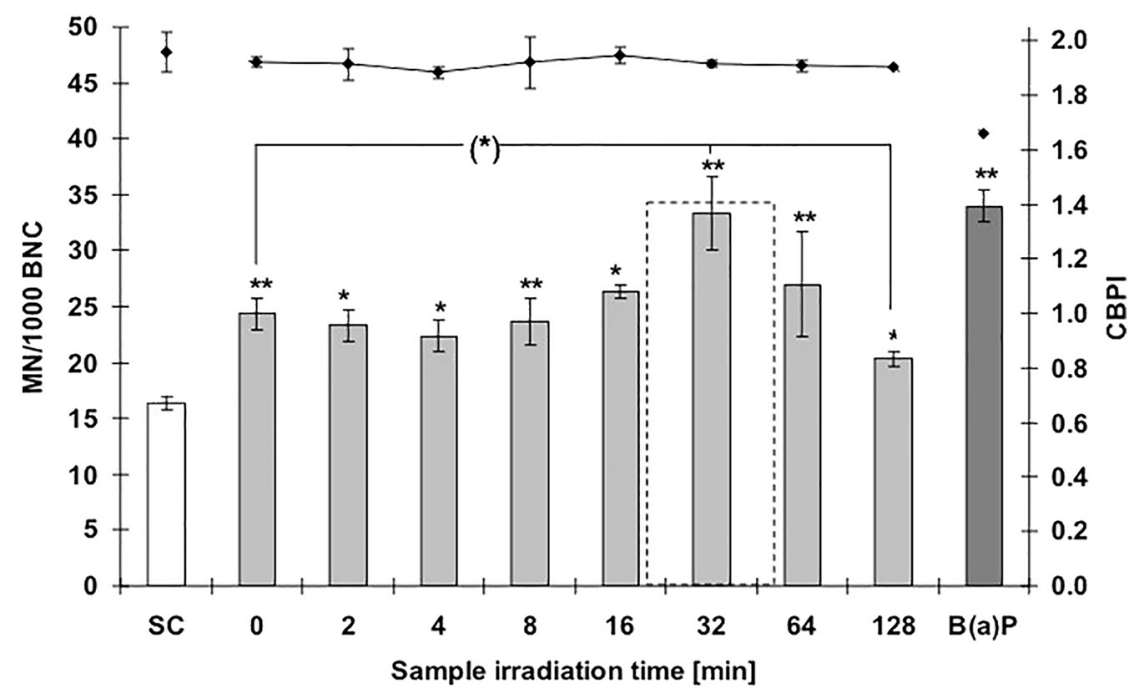

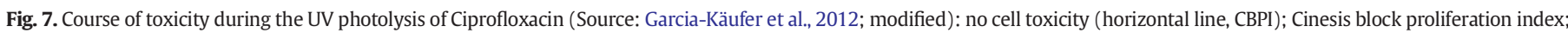
window of genotoxicity (bars; dashed rectangle); micro nucleus test; B(a)P Bonzo(a)pyrene-positive control; SC-solvent control. 
Jones et al. (2007) demonstrated them to have very good elimination capacities. They also have a high life cycle outcome. But slow-sand filters cannot be used to produce the same amount of water per unit time and unit cross sectional area. That is a limitation in urban environment as there are large quantities of water needed.

Another approach is to apply light and/or oxidants such as ozone or hydrogen peroxide or electrochemical treatment. A chemical reacts (or does not) with a specific reagent such as ozone, chlorine, hydroxyl radicals and other agents such as ferrate (VI) or electrons provided by electrodes according to its individual chemical structure. Formation of different TPs by different treatment applies even for compounds within a group of similar substances. By each oxidative treatment, a variety of TPs with often-unknown properties is generated, especially if radicals are involved (Fatta-Kassinos et al., 2011). The hydroxyl radical is a highly reactive species. Therefore, it reacts with low selectivity with nearly every organic molecule present resulting in many TPs (Längin et al., 2009; Margot et al., 2013; Trautwein et al., 2014; Lambropoulou and Nollet, 2014; De Laurentiis et al., 2014; Antonopoulou and Konstantinou, 2016; Matsushita et al., 2016). Therefore, most advanced oxidative treatment processes such as the photo-driven ones, (photo)Fenton reaction or hydrogen peroxide based ones or ozonation often lead to the generation of an important number of TPs as they are based on free hydroxyl radicals (as exemplified in Fig. 6). Nödler et al. (2013) for example found up to ten or more TPs resulting from one parent compound while Dionysiou's group reported in some cases formation of more than 15 TPs from the breakdown of one single parent contaminant (Antoniou et al., 2008a, 2008b; He et al., 2015; Abdelraheem et al., 2016). The individual relative number and share of TPs depend on the applied reaction conditions and treatment duration (Figs. 5, 6). It is often assumed that the concentration of the TPs is by far lower than that of the parent compound. Recently, it was found that the molar concentrations of some TPs can be higher than that of the parent compound (Ter Laak et al., 2013, Trautwein et al., 2014). Furthermore, TPs can also be a result from reaction of MPs with other water contaminants (Wendel et al., 2016).

There is still an unproven thesis that oxidative treatments generate better biodegradable TPs (Oller et al., 2011). This assumption relies on the fact that several oxidation reactions lead to the integration of hydroxyl groups into the parent molecule, which in turn will improve biodegradability as the molecule is already oxidized by a certain degree. However, biodegradation just occurs if a molecule can cross the bacterial membrane and this may not occur if a molecule is too polar. Furthermore, this molecule has to fit into the enzyme's "pocket" for appropriate interaction with its active center. Accordingly, an increasing number of studies reported that polar TPs which have been generated e.g. by oxidative treatment do not have a better biodegradability than their parent compounds but may even be recalcitrant too (e.g. Khaleel et al., 2017; Herrmann et al., 2015; Rastogi et al., 2014, 2015a, 2015b). Other studies even demonstrated that biodegradation of photo TPs led to the generation of new, recalcitrant bio-TPs (Herrmann et al., 2016b; Gutowski et al., 2015). In other words, reducing the concentration of a given parent compound by a treatment does not necessarily imply lower risk. In contrast, the opposite may be true in many cases. Examples are the formation of $\mathrm{N}$-nitrosodimethylamine (NDMA) by oxidative treatment such as ozonation, chloramination or chlorination of wastewater, or potable water containing pharmaceuticals, pesticides, and other chemicals including releases from ultrafiltration membranes followed by oxidative treatment (Marti et al., 2015, Mitch and Sedlak, 2002, Zeng and Mitch, 2015, Hanigan et al., 2015, Li and Lin, 2015, Li et al., 2011). If chemicals reach potable water treatment, TPs are also formed within the treatment processes (Postigo and Richardson, 2014; Schmidt and Brauch, 2008). NDMA can also be formed from TPs as has been demonstrated for a TP of a fungicide (Schmidt and Brauch, 2008). NDMA is hepatotoxic at low concentrations and is a suspected human carcinogen. The US Environmental Protection Agency (EPA) has set the threshold for NDMA concentration in drinking water to $7 \mathrm{ng} \mathrm{L}^{-1}$. It does not readily biodegrade, adsorb, or volatilize. As such, it cannot be removed e.g. by activated carbon which is often applied as a finishing purification step of potable water. If the latter is done by ozonation or chlorination, NDMA can also form. Given the fact that ozonation and chlorination are widely spread in use and often indispensable for drinking water and effluent treatment (Benami et al., 2016), this can constitute a potential threat and could be called a rebound effect.

Chlorine is widely applied as an oxidant for disinfection of urban wastewater and potable water e.g. in the U.S.A. and other countries. Reaction of residual chlorine in tap water for example leads to the generation of chlorinated parabens from non-chlorinated ones. The latter are more persistent than the parabens themselves (Li et al., 2015a, 2015b). The calculated $\log \mathrm{P}_{\mathrm{ow}}$ (unpublished results, calculated with Multicase Software Package CaseUltra) of chlorinated parabens indicates that they are less polar than the parent compounds and have a potential to accumulate along the food web and in humans. Furthermore, the even lower polarity of the chlorinated parabens compared to that of the parent compounds, makes their uptake into bacterial cells more difficult. The lower polarity also increases bioaccumulation. In fact, in this case, advanced treatment and, disinfection leads to TPs that may have properties that may classify them as persistent organic pollutants (POPs). Ironically, this technology is adopted in order to inactivate microorganisms but generates POPs. It might be that those less polar TPs are better adsorbed on suitable sorbent surfaces. For example, in the case of treatment of water containing parabens by chlorination or unintended reaction of parabens with residual chlorine, a combination with a subsequent treatment by activated carbon may be helpful, as less polar compounds are formed by chlorination which are well known to adsorb effectively onto activated carbon (Worch, 2012). In many cases toxic byproducts of chlorination and other oxidative processes are formed by the reaction with background organic matter. In the U.S.A., enhanced coagulation is therefore applied for this reason but not all the dissolved organic carbon and MPs are removed. In addition, toxicity of treated water may also be associated with background organic matter, the structure of which has not been fully characterized, providing thus additional challenges in the effort to fully assess toxicity of treated water relevant to field applications (Michael-Kordatou et al., 2015). In Germany, for example, chlorination in potable water treatment has been abandoned decades ago because of the possible formation of toxic and accumulative organo chlorine reaction products with DOM including known pollutants. Ozone or UV treatment is applied instead to avoid the formation of these toxic reaction byproducts (i.e. TPs). However, probably only the type and number of TPs formed have thereby changed. The point here is not to abandon disinfection by UV or ozone but to reduce the presence of MPs to reduce or avoid formation of toxic TPs by disinfection.

In the case of metals, oxidizing methods will probably generate different species, i.e. atoms of different oxidation state with again different toxicity and eco-toxicity. For example, the formation of very toxic metal species, e.g. gadolinium (III) or chromium (VI) by oxidative treatment is unknown so far. As for heavy metals, we know from research that has already been carried out decades ago, that some sorb to a certain extend to the sewage sludge but a complete elimination doesn't occur in conventional treatment plants. As for rare earth metals and some metalloids it has to be mentioned that they can form several oxidation states with often not fully known toxicity and eco-toxicity. It has also been learned only recently that neither conventional nor advanced effluent treatment can fully remove microplastics which are for example used in personal care products or are generated in the washing of clothing (Carr et al., 2016; Chang, 2015; Murphy et al., 2016; Van Wezel et al., 2016).

Summarizing, so far, based on the discussion on the elimination, transformation, and degradation behavior of most substances in advanced treatment, data are still sparsely available. Conventional and advanced treatment can eliminate some of the compounds but by far not all of them, even if combinations of treatments are applied. The overall result strongly depends on the individual compounds, concomitant compounds as well as specific treatment conditions. Especially 
oxidative treatments but also others result in the formation of new, often not known compounds. Advanced treatment comes along with increased costs and handling of hazardous chemicals in some cases. Furthermore, advanced treatment will for sure not be available in all countries neither in the near nor in the more distant future.

\section{Limited knowledge on the effects of substances}

At best, MPs are undesirable chemicals in aquatic systems. However, it was already found that the MPs constitute a risk to the environment and the consumers (Magdeburg et al., 2014; Hanigan et al., 2015). Several studies have shown that MPs, including TPs, have unwanted effects on environmental organisms at quite low concentrations (Triebskorn et al., 2004; Triebskorn et al., 2007; Brodin et al., 2013; Vincze et al., 2015). Additionally, some MPs can interact with the DNA (e.g. several cytostatic drugs, Allwood et al., 2002, Mosby, 2016, Kümmerer and Clark, 2016) or act as endocrine disruptors. They urge the scientific community to look into them with great attention.

As for effect assessment, many endpoints to be assessed exist, and also there are often many tests for each of the endpoints. E.g. there are eight different Ames test variants to assess mutagenicity, let alone the many tests for genotoxicicty, endocrine activity, neurotoxicity and so on. As for ecotoxicology, the situation is even more challenging. In other words, the high number of chemicals with different properties makes a complete assessment extremely difficult or even impossible (Diamond et al., 2015; MacLeod et al., 2014; Persson et al., 2013; Rockström et al., 2009; Steffen et al., 2015). Especially, the increasing volume of new substance groups such as nanoparticles and micro plastics have to be considered. They present new and big methodological challenges (Krug, 2014). Pharmaceuticals and nanoparticles are often assessed using conventional, sometimes standardized tests. However, they have been developed for plain chemicals and their applicability for the mentioned new chemical entities is not clear yet. TPs add significantly to this challenge. Because of this situation research most often deals with a few molecules that are part of a bigger group of chemicals (e.g. pharmaceuticals) that are for example easy to measure or available for testing (Daughton, 2016). As there are so many TPs and as they are new chemicals that are most often not commercially available, a proper assessment would be impossible. Computational methods are increasingly used for the assessment of chemicals and provide first indications on TPs environmental characteristics (e.g. Menz et al., 2017). However, for the model development of new groups of molecules and endpoints the experimental data basis is still scarce which results in a limited availability of good quality models for predictions. Even for clearly defined and well-established end points such as mutagenicity, there are serious challenges for a sound assessment of TPs in general and also for in silico approaches (Toolaram et al., 2014).

Among other points, substances nowadays rated as harmless may turn out to be effective even at low concentrations. Endocrine disrupting chemicals and earlier mutagenic or carcinogenic compounds are historical examples. Nowadays for the assessment of chemicals the endocrine activity is seen as one of the most important properties, while it was not considered 30 years ago. Therefore, it can be expected that such properties as neurotoxicity and thyroid disruption will probably be increasingly considered endpoints in the near future.

As already discussed above, we neither know which are the future chemicals used and which MPs in the aquatic environment are linked to them, nor the fate and behavior of these MPs, including formed TPs, within the different treatment processes and the environment. Most probably the determination of all possible effects of a certain chemical in advance will be impossible which in turn questions the Setting of reliable thresholds or trigger values for action. For example, only recently some chemicals are considered to contribute to environmentally induced neurological diseases in low- and middle-income countries (Tshala-Katumbay et al., 2015). This could be also applied to behavioral effects of contaminants on environmental organisms, which impact populations and ecosystems (Oaks et al., 2004; Brodin et al., 2013). Only a very minor share of contaminants has been investigated in this respect so far (Bernhardt et al., 2017).

The toxicity of a mixture of parent compounds and TPs generated by an advanced or conventional treatment depends not only on the specific treatment conditions and the parent compound itself but also the duration of the specific advanced treatment process applied and can result in "windows" of increased toxicity e.g. genotoxicity (Isidori et al., 2005; Garcia-Käufer et al., 2012; Vasquez et al., 2013; Antonopoulou and Konstantinou, 2016; Rozas et al., 2016), which makes it very challenging to select the appropriate treatment time and technology for a single compound let alone the case of mixtures which is the reality in practice. Compounds are assessed and regulated one by one; if regulated at all. Knowledge and data allowing a better understanding of the significance of substance mixtures in the environment is still little including their fate and effects (EU, 2018). However, mixtures of chemicals are present in our environment and can be more potent than the single compounds (Silva et al., 2002). Researchers are finding that although the effects of a single chemical may not be effective, those of mixtures may impose deleterious synergistic effects (Silva et al., 2002; Kortenkamp and Faust, 2018). The possible effect of mixtures of parent compounds on the environment and human health is often unknown as for most compounds full data sets are not available and will perhaps never be, let alone the numerous TPs.

During the last two decades, it has been made evident that crops can take up pharmaceuticals. However only a few studies existed back then. It is during the recent years that we have more and more studies demonstrating clearly the uptake (see for example Christou et al., 2017a, 2017b). Only recently it was found that healthy humans that consumed reclaimed wastewater irrigated crops have been shown to excrete carbamazepine and its human metabolites (Paltiel et al., 2016). This demonstrates the transfer of these compounds to humans not just by water directly but also indirectly by food. Although the daily intake of parent compounds can be calculated, data on effects referring to life-long uptake of chemicals and their TPs are not available and will probably never be. Furthermore, in the era of economy-driven technology and impact driven science, often the quality of (toxicity) data is insufficient (Harris and Sumpter, 2015).

Recently, several studies have shown that wastewater treatment by ozone may result in a selection of antibiotic resistance genes (ARGs) in the effluent (Lüddeke et al., 2015; Moreira et al., 2016; Alexandera et al., 2016; Czekalski et al., 2016). This adds to the prohibition of the use of such treated effluents for drinking water purposes or for (waste) water reuse e.g. for irrigation of agricultural land. Even if treated water effluents would be only used for irrigation of lawn or recreational purposes such compounds can reach groundwater and contaminate formerly clean water resources (Drewes et al., 2003).

We would also like to underline that time lags have to be accounted for (Kümmerer, 1996; Weiser et al., 2017). Chemical pollution of the environment is slow in some respect, often detected only with a considerable time lag. Reasons are the availability of awareness and knowledge e.g. for new compounds introduced into the market or being constituents of complex products, proper equipment, apparatus and technology. Some publications dealing with that issue are available, however, they are not always taken up by the scientific community. Before the advent of liquid chromatography (LC) and coupled with mass spectrometry (LC-MS), polar compounds such as many pharmaceuticals were not or only little accessible for analysis albeit several of them were around for decades already. However, even nowadays it may be difficult to receive pure compounds for analysis and testing. Experiences gained from the example of pharmaceuticals show that mainly so-called "old" or legacy pharmaceuticals have been studied or are still studied. Often they have been replaced by new ones or will be in the near future. Knowledge about that is often not available to the scientific community. Still nowadays research often focuses on the same few compounds and well established methods being the "pets" of the research community. 
Therefore, very often the compounds of the past are studied instead the new ones. That holds also for effect assessment.

A large variety and variability of environmental processes occur at regional or even global scales over long time periods. The example of POPs and the ozone depleting compounds demonstrates this very well (Kümmerer, 1996; Diamond et al., 2015). Accordingly, not just pollution but the adverse effects caused by chemical pollution may become manifest on all scales from local to global, and they may become manifest also on different time scales, some only within decades. The situation is complicated by the fact that different organisms have different sensitivity in different life stages and have different life times. In fact, these multi-scale aspects of chemical pollution make a sound risk assessment difficult if not impossible as well as a real sound selection of compounds to focus on apart from the mutagenic, genotoxic and endocrine active ones.

As already mentioned nanoparticles (and microplastics) present new methodological challenges as well as for risk assessment (Krug, 2014) which may result in wrong results and anticipated risks.

The high number, diversity, multiple properties, and effects possibly associated with the presence of chemicals in the aquatic environment make it impossible to set a maximum allowable concentration and diversity of chemicals present in water within the global boundary approach. May be that is a reason why the issue is treated as there were none (Rockström et al., 2009) or summarized with genetically modified organisms as "new entities" (Steffen et al., 2015).

Summarizing, the huge number of different chemical entities present in effluents and the aquatic cycle and its variability with regard to the type, properties, concentration, location and time is probably an insurmountable challenge for currently available analysis, treatment and risk assessment approaches.

\section{Proactive action and long-term strategies}

Overall, the above-discussed points clearly demonstrate the serious limitations and the non-sustainability of just focusing on end-of-pipe treatment and its often incremental improvement. In fact, we just primarily eliminate the parent compounds and forget about most of the rest. Therefore, a much more sustainable water management is necessary addressing the challenge of MPs especially where boundary conditions for solely technical measures are not available and may neither be established. This by no means should lead to minimize the efforts to improve wastewater treatment but to provide more integrated approaches which not only focus on the end of the pipe. Therefore, input prevention measures have to handle and design effluents and chemicals in such a way that centralized treatment and surface water environments can cope with the pollutant loads and concentrations. Input prevention measures enable, therefore, an adaptation of the end-of-pipe approaches in a more targeted and more effective way. There will be no "one and only" strategy or technology for sufficient input prevention but rather a variety of applicable and combinable measures. The application of the principles of pollution prevention, the precautionary principle, the principles of green and sustainable chemistry will give guidance.

In general, it is necessary to attain a better knowledge where, why and in which products chemicals are used and on which pathways they are released to the aquatic cycle. Knowing the specific reasons and properties of chemicals or for their usage and application in industry, commerce, agriculture, households, healthcare, and related products is a key for better understanding the functionality certain substances offer for their application and therefore the potential emission sources.

The exemplified input prevention measures listed below may be considered as a preliminary collection of possible approaches and by no means can be considered as exhaustive. However, they are a good starting point and should trigger discussions and further developments. Some Insights are well known since long; like e.g. that the "avoidance is better than reduction". To consider all options instead just one is important. Some may rather be implemented on basis of local or regional catchment areas, others on an operational basis; while others will require political (EU, 2015; EU, 2017; U.S. EPA, 2017; BMUB/UBA, 2017) and social rethinking first which will take some more time.

Some of the measures given below are part of already existing regulations, guidelines, and principles e.g. EU (1996). Some of the new approaches are offered by green chemistry (Anastas and Warner, 1998) and sustainable chemistry (Kümmerer and Clark, 2016; Kümmerer, 2017), that are already available and just have to be put into practice on a broader range, while others go beyond that (Kümmerer et al., 2018).

- Although, most countries have regulations in place to achieve zero discharge of pollutants to waterways, the enforcement has to be improved. The successful example of India, where about 600-700 dyeing factories were closed down by the government and a reopening was just allowed once the zero discharge was in place, demonstrate that zero discharge could be made mandatory for textile and chemical industries. The polluted water is treated inside the factory now.

- In most countries, fee for wastewater discharge into the public sewer system is most often used for the maintenance of the piping and other equipment but not because of the presence of pollutants in the wastewater. However, in India for example, many small/medium sized factories discharge their effluent to a company owned treatment plant or public one. In such cases the facility charges the factory based on the type of load, its chemical oxygen demand value and the volume.

- In some countries (e.g. Germany) another charge has to be paid (pollutant charge) if the effluent of the treatment plant does not meet certain standards. Additional chemical parameters such as concentration of $\mathrm{N}$ or P or selected heavy metals or the sum for halogenated organic chemicals are applied to set the amount of money to pay for discharge of treated effluent into the aquatic environment. For example, the inclusion of halogenated compounds had the effect that companies reclaimed halogenated and persistent solvents, used less of them or separately collected them before they ended up in the wastewater. In a next step more specific endpoints such as endocrine activity and others or additional specific compounds e.g. based on the European Water Framework Annex List and additional metals such as some rare earth metals should be added to address the less concentrated micropollutants too.

- Improvement of separation of wastewater streams as it is common practice already in some industries, i.e. management at the source for lower chemical diversity therein and thereby allowing for a more-targeted treatment including retaining of pollutants. In combination with adapted onsite treatment measures the contribution of MPs to wastewater and therefore the inflow pollution to WWTP can be minimized.

- Source apportionment of MPs, onsite separation of wastewater streams and their onsite treatment for reuse is an applicable integrated approach to use treated wastewater as a substitute for potable water. That is especially of interest in arid and semi-arid zones (Maimon and Gross, 2018; Fatta-Kassinos et al., 2016; Oron et al., 2014). That would mean also to think of a different infrastructure of the future considering local conditions and intended usage. Again, in some sectors and regions that is already a reality.

- Minimizing the amounts and diversity of chemicals within production, e.g. by simplifying chemical reactions (Greener Industries; Dunn et al., 2004) and in products. For example, industry has claimed for many years that silicones are indispensable in certain personal care products such as shampoos and hair conditioners. Interestingly, since silicones are more and more in the focus of discussion some companies including big ones are advertising "silicone free" products.

- Increased use of substances in closed loops within production. As long as they are used only in closed loops they should be very stable in order to allow for longer use. 
- To have a more extensive knowledge on the specific ingredients of certain products such es household chemicals, minor constituents of personal care products but also adjuvants in pharmaceuticals, biocides, pesticides and other products of the chemical industry such as plastics, electronic equipment, faced and other building materials to mention just a few. In addition to the name of a chemical including the IUPAC International Chemical Identifier (InChI) should be given to allow for a quick and unambiguous identification of constituents (Heller et al., 2015). That would also allow to better identify hot spot and/or diffuse sources as well as targeted analytical programs. All these pieces of information should be made available by a public and easily accessible data base.

- Reasons for the usage of certain substances in industry, commerce, agriculture, households, healthcare, etc. should be better known from a molecule and product design perspective. That means better knowledge is needed about the functionality certain substances offer for their usage. That would among others allow for new serviceoriented business models that result in the use or at least loss of less chemicals (UNIDO, 2016; Daughton, 2014; Streek et al., 2011).

- Compliance and optimization of the administration of pharmaceuticals (Straub, 2016, Daughton, 2014) and a proper assessment and selection of adjuvants and chemicals in manufacturing, e.g. of pharmaceuticals (Wirz et al., 2015).

- In conventional effluent treatment and surface water easily and completely mineralising chemicals (see also next point) should be used only in products when constituents may reach effluent during manufacturing, application and usage. That holds through out their life time. For example, replacing plastic microbeads in cosmetics by cellulose microbeads or nanoparticles that are easy to synthesize and are fully biodegradable (Kümmerer et al., 2011). The same holds for example for organic ingredients of building materials such as biocides in facades or flame retardants or plasticisers in polymers. To move this forward, legislation is needed calling for ready biodegradability of chemicals that can or will end up in wastewater by proper use.

- If organic chemicals and products were designed that effluent and water treatment or processes in the environment would lead to fast and complete mineralization ("benign by design", Anastas and Warner, 1998, Rieger et al., 2002, Kümmerer, 2007, Kümmerer and Hempel, 2010, Leder et al., 2015) that would work everywhere where such chemicals and pharmaceuticals reach the aquatic cycle. Examples from other product groups such as fragrances and ionic liquids are also available as well as some general rules of thumb for such a design (Boethling et al., 2007; Boethling, 2011; Rastogi et al., 2014, 2015a, 2015b; Ceriani et al., 2015; Haiß et al., 2016; Toropov and Toropova, 2018).

- Improving the management of substance flows, material flows and product flows on different spatial (e.g. local, regional, national, and global) and temporal scales level including individual companies, their subsidies or specific branches (Kümmerer, 1996; Kümmerer, 2017; Kümmerer et al., 2018).

- Considering the complete flows for individual substances, respectively, in different locations, e.g. within one area not just within a single company.

- Regarding the entire set of flows containing the compound of interest i.e. on all sources of a substance; not just one or just its production (e.g. by creating balance sheets).

- Considering all flows of a substance in different applications and products.

- Reducing the diversity of chemicals and materials as well as their temporal dynamics in the different applications and products that may be introduced into the aquatic cycle making their flows thereby as uniform as possible and thereby as predictable and handling as possible.

- Some pollutants are of natural origin such as algae toxins. As for other contaminants of the aquatic environment a better understanding of conditions favoring them and subsequently the creation of conditions in natural water bodies that prevent the formation of such toxins is needed.

- Understanding pollutants' elimination in potable water treatments as a "police filter" i.e. a last rationale, i.e. it should only be understood as a safety barrier in case such a pollutant really gets there rather than as a routine.

- Developing service based and other new business models that lead to less use of chemicals or pharmaceuticals or even an approach without needing chemicals or pharmaceuticals for a certain service (Kümmerer, 2017). The leading starting question here is which functionality a chemical or pharmaceutical does offer and which nonchemical alternatives exist. For example, in a hospital the objective is a certain standard of hygiene not the highest possible consumption. Disinfectant manufacturers can deliver both knowledge and training on the one hand and disinfectant where needed. If the company will be paid for maintaining a certain standard of hygiene it would have an interest in applying disinfectants only where is actually necessary and/or if training measures are not successful as it will need less disinfectant. They save costs by saving disinfectants; they will not have to pay for chemicals and other resources they need to manufacture the disinfectant. It then generates more of the financial turnover and revenue e.g. by delivering education and training courses as well as consultation (Streek et al., 2011; UNIDO, 2016).

- Economic considerations have to include all costs, i.e. the internalization of external costs is indispensable - both in macroeconomic and microeconomic terms. A slight modification of the production process may result in significant extra costs for the management of wastewater and drinking water. Possibly with allocation of external costs sometimes it could be better to stick to the "old" substance which allows a much better estimation of risks thanks to data and knowledge on environmental fate and effects being available already ("regrettable substitute problem").

- Education at various levels has to be intensified (kindergarten, middle and high school, college, university), including information to the wider public (Wieck et al., 2018) on the general fate and effects of chemicals and pharmaceuticals in the environment and how to prevent their input into wastewater and the aquatic environment.

- Considering the precautionary principle is another important building block of a more sustainable water future: "If there is nothing to be seen, it doesn't mean there is nothing and/or that nothing happens" (example is the toxicity of mixtures of compounds (Silva et al., 2002) or of unknown TPs or of not yet known/taken into consideration of toxicity, or of the fact that elimination of a parent compound doesn't necessarily imply complete mineralization); long-term risks might go beyond the usually applied cause-effect analysis etc. (Renn and Keil, 2009).

\section{Conclusions}

Undoubtedly the conventional treatment of wastewater is an important and indispensable contribution to human health and protection of the environment. Furthermore, advanced treatment using innovative technologies might have more potential in treating water, especially if both water and urban wastewater treatment has to cope with a very high number of different chemicals with individual properties. However, with the ever-increasing number (i.e. diversity) and volume of chemicals, materials and products manufactured, used and introduced into the aquatic cycle there are clear limitations for exclusive end-ofpipe strategies. Therefore, it is quite understandable that each of the treatments, or even combination of several treatments, most often removes only a small fraction of the parent compounds. Nowadays the situation we are facing in a modern "chemicalized" world focusing primarily on water treatment cannot offer a solution to the water problems 
to such an extent as it would be needed both in developed and in developing countries. In the latter often no or only little effluent treatment facilities is in place and at the same time alternative measures for wastewater treatment and reuse are urgently needed. This demonstrates that integrated approaches are necessary tackling the sources of pollution, to minimize the chemical diversity and temporal dynamics of the composition of wastewater, in combination with using adapted treatment strategies.

Additionally, the advent of advanced chromatographic methods, high-resolution mass spectrometry and, recently, the non-target screening, demonstrates clearly that the identification of chemical contaminants will be an endless quest. Thus, such capabilities will allow quantification of many known contaminants (i.e., regulated, emerging) at continuously lower concentrations and identification/quantification of completely new contaminants and TPs. In turn, this will consider implementation of continuously stringent regulations that will necessitate the development and application of adapted risk assessment tools and more efficient and robust treatment technologies. All these will create a constantly moving target that we will need to follow in an endless journey. In fact, numerous follow-up problems go along with it too. That can be avoided or at least reduced by an increased focus and implementation of the measures discussed herein, with regard to source control. Most of the measures need an interdisciplinary cooperation of users, chemists, water scientists, and engineers, to mention a few only. That is of significance for research, implementation into practice and education.

According to "Ockham's Razor", an approach should be as simple as possible. If the entry of chemical substances into the water is considerably reduced, the wastewater treatment among other building blocks can better fulfil the requirements. In that case, treated wastewater could be reused safely and sustainably and this will have the potential to open a new horizon for establishing closed water cycles and closing water balances. This view is not new, but it is an indispensable prerequisite to ensure a sustainable water management. It fits very well to the UN Environment Programme for the sustainable chemicals management and sustainable chemistry as only recently adopted by the UNEPs second general Environmental Assembly (UNEA-2, UNEP, 2016).

\section{References}

Abdelraheem, W.H.M., He, X., Komy, Z.R., Ismail, N.M., Dionysiou, D.D., 2016. Revealing the mechanism, pathways and kinetics of UV254nm/ $\mathrm{H}_{2} \mathrm{O}_{2}$-based degradation of model active sunscreen ingredient PBSA. J. Chem. Eng. 288, 824-833.

Achzet, B., Reller, A., Zepf, V., Rennie, C., Ashfield, B.P., Simmons, M.J., 2011. Materials Critical to the Energy Industry. An Introduction. University of Augsburg, Germany.

Alexandera, J. Knopp, G., Dötscha, A., Wieland, A , Schwartz, T., 2016. Ozone treatment of conditioned wastewater selects antibiotic resistance genes, opportunistic bacteria, and induce strong population shifts. Sci. Total Environ. 559, 103-112.

Allwood, M., Stanley, A., Wright, P., 2002. The Cytotoxics Handbook. Radcliffe Medica Press, Oxford.

Amic, R.S., Burgess, E.H., 2000. Exfiltration in sewer systems. https://nepis.epa.gov/Exe/ ZyPDF.cgi/2000E6PB.PDF?Dockey=2000E6PB.PDF, Accessed date: 17 January 2018

Amildon Ricardo, I. Paiva, V.A.B., Paniagua, C.E.S., Trovó, A.G., 2018. Chloramphenicol photo-Fenton degradation and toxicity changes in both surface water and a tertiary effluent from a municipal wastewater treatment plant at near-neutral conditions. Chem. Eng. J. 347, 763-770.

Anastas, P.T., Warner, J.C., 1998. Green chemistry: theory and practice. Oxford University Press, New York.

Antoniou, M.G., Shoemaker, J.A., Armah, A., de la Cruz, A.A., Dionysiou, D.D., 2008a. LC/MS MS structure elucidation of reaction intermediates formed during the $\mathrm{TiO}^{\circ}$ photocatalysis of microcystin-LR. Toxicon 51, 1103-1118.

Antoniou, M.G., Shoemaker, J.A., de la Cruz, A.A., Dionysiou, D.D., 2008b. Unveiling new degradation intermediates/pathways from the photocatalytic degradation of microcystin-LR. Environ. Sci. Technol. 42, 8877-8883.

Antonopoulou, M., Konstantinou, I., 2016. Photocatalytic degradation and mineralization of tramadol pharmaceutical in aqueous $\mathrm{TiO}_{2}$ suspensions: evaluation of kinetics, mechanisms and ecotoxicity. Appl. Catal., A. 515, 136-143.

BC Cancer, 2018. British Columbia cancer drug manual. http://www.bccancer.bc.ca/ health-professionals/clinical-resources/cancer-drug-manual, Accessed date: 10 February 2018.

Benami, M., Gillor, O., Gross, A., 2016. Potential microbial hazards from graywater reuse and associated matrices: a review. Water Res. 106, 183-195.

Bernhardt, E.S., Rosi, E.J., Gessner, M.O., 2017. Synthetic chemicals as agents of global change. Front. Ecol. Environ., 1-7 https://doi.org/10.1002/fee.1450.
Bester, K., 2007. Personal Care Compounds in the Environment: Pathways, Fate and Methods for Determination. Wiley VCH, Weinheim.

BMUB/UBA (Hrsg.), 2017. Policy-Paper Empfehlungen des Stakeholder-Dialogs "Spurenstoffstrategie des Bundes» an die Politik zur Reduktion von Spurenstoffeinträgen in die Gewässer. In: Hillenbrand, T., Tettenborn, F., Bloser, M. (Eds.), Bonn: Bundesministerium für Umwelt, Naturschutz, Bau und Reaktorsicherheit/Dessau: Umweltbundesamt https://www.dialogspurenstoffstrategie.de/spurenstoffe-wAssets/docs/PolicyPapier_FINAL.pdf, Accessed date: 20 January 2018.

Boethling, R.S., 2011. Incorporating environmental attributes into musk design. Green Chem. 13, 3386-3396.

Boethling, R., Sommer, E., Di Fiore, D., 2007. Designing small molecules for biodegradability. Chem. Rev. 107, 2207-2227.

Brodin, T., Fick, J., Jonsson, M., Klaminder, J., 2013. Dilute concentrations of a psychiatric drug alter behavior of fish from natural populations. Science 339, 814-815.

Burkhardt, M., Kupper, T., Hean, S., Haag, S., Schmid, P., Kohler, M., Boiler, M., 2007. Biocides used in building materials and their leaching behavior to sewer systems. Water Sci. Technol. 56, 63-67.

Capela, D., Alves, A., Homem, V., Santos, L., 2016. From the shop to the drain - volatile methylsiloxanes in cosmetics and personal care products. Environ. Int. 92-93, 50-62. https://doi.org/10.1016/j.envint.2016.03.016.

Carr, S.A., Liu, J., Tesoro, A.G., 2016. Transport and fate of microplastic particles in wastewater treatment plants. Water Res. 91, 174-182.

Carson, R.L., 1962. The Silent Spring. Houghton Mifflin, USA.

Ceriani, L., Papa, E., Kovarich, S., Boethling, R., Gramatica, P., 2015. Modeling ready biodegradability of fragrance materials. Environ. Toxicol. Chem. 34, 1224-1231.

Chang, M., 2015. Reducing microplastics from facial exfoliating cleansers in wastewater through treatment versus consumer product decisions. Mar. Pollut. Bull. 101, 330-333.

Christou, A.T , Agüera, T., Bayona, V., Cytryn, E. Fotopoulos, V., Lambropoulou, D. Manaia, C.M., Michael, C., Revitt, M., Schröder, P., Fatta-Kassinos, D., 2017a. The potential implications of reclaimed wastewater reuse for irrigation on the agricultural environment: the knowns and unknowns of the fate of antibiotics and antibiotic resistant bacteria and resistance genes - a review. Water Res. 123, 448-467.

Christou, A., Karaolia, P., Hapeshi, E., Michael, C., Fatta-Kassinos, D., 2017b. Long-term wastewater irrigation of vegetables in real agricultural systems: concentration of pharmaceuticals in soil, uptake and bioaccumulation in tomato fruits and human health risk assessment. Water Res. 109, 24-34.

Chung, S.W., Wu, A.H.T., 2017. Determination of butyltins, phenyltins and octyltins in foods with preservation of their moieties: a critical review on analytical methods. J. Chromatogr. A 1505, 18-34.

Czekalski, N., Imminger, S., Salhi, E., Veljkovic, M., Kleffel, K., Drissner, D., Hammes, F., Bürgmann, H., Von Gunten, U., 2016. Inactivation of antibiotic resistant bacteria and resistance genes by ozone: from laboratory experiments to full-scale wastewater treatment. Environ. Sci. Technol. 50, 11862-11871.

Daughton, C.G., 2014. Eco-directed sustainable prescribing: feasibility for reducing water contamination by drugs. Sci. Total Environ. 493, 392-404.

Daughton, C.G., 2016. Pharmaceuticals and the environment (PiE): evolution and impact of the published literature revealed by bibliometric analysis. Sci. Total Environ. 562, 391-426.

De Laurentiis, E., Prasse, C., Ternes, T.A., Minella, M., Maurino, V., Minero, C., Sarakha, M., Brigante, M., Vione, D., 2014. Assessing the photochemical transformation pathways of acetaminophen relevant to surface waters: transformation kinetics, intermediates, and modelling. Water Res. 53, 235-248.

DeLoitte, Anonymus, 2016. Global health care outlook. http://www2.deloitte.com/global/ en/pages/life-sciences-and-healthcare/articles/global-health-care-sector-outlook. html, Accessed date: 25 October 2016.

Diamond, M.L., de Wit, C.A., Molander, S., Scheringer, M., Backhaus, T., Lohmann, R. Arvidsson, R., Bergman, T., Hauschild, M., Holoubek, I., Persson, L., Suzuki, N., Vighi, M., Zetzsch, C., 2015. Exploring the planetary boundary for chemical pollution. Environ. Int. 78, 8-15.

Drewes, J.E., Horstmeyer, N., 2016. Recent developments in potable water reuse. In: FattaKassinos, D., Dionysiou, D., Kümmerer, K. (Eds.), Advanced Treatment Technologies for Urban Wastewater Reuse, Handbook Environmental Chemistry. Vol. 45. Springer, pp. 269-290.

Drewes, J.E., Heberer, T., Reddersen, K., 2003. Fate of pharmaceuticals during ground water recharge. Ground Water Monit. Remidiat. 23, 64-72.

Dunn, P., Galvin, S., Hettenbach, K., 2004. The development of an environmentally benign synthesis of sildenafil citrate (Viagra ${ }^{\mathrm{TM}}$ ) and its assessment by green chemistry metrics. Green Chem. 6, 43-48.

Ebert, I., Amato, R., Hein, A., Konradi, S., 2014. Medicinal Products in the Environment. Avoid, Reduce, Monitor (Arzneimittel in der Umwelt, reduzieren, überwachen). Umweltbundesamt, Dessau-Roßlau.

El-Taliawy, H., Casas, M.E., Bester, K., 2018. Removal of ozonation products of pharmaceuticals in laboratory moving bed biofilm reactors (MBBRs). J. Hazard. Mater. 347, 288-298.

Erickson, B.E., 2017. How many chemicals are in use today? C\&EN 95, 23-24.

European Commission, 2015. Communication from the commission to the European parliament and the council. The Water Framework Directive and the Floods Directive: Actions Towards the 'Good Status' of EU Water and to Reduce Flood Risks/* COM/ 2015/0120 Final */., 9.3.2015.

European Environmental Agency, 2018. European Waters. Assessment of Status and Pressures 2018. Report No 7/2018.

European Union, 1996. Council directive 96/61/EC concerning integrated pollution prevention and control. Off. J. L 257, 26-40.

European Union, 2015. http://ec.europa.eu/environment/water/water-framework/pdf/ 4th_report/CSWD\%20Report\%20on\%20WFD\%20PoMs.pdf, Accessed date: 25 October 2016. 
European Union, 2017. http://ec.europa.eu/environment/chemicals/non-toxic/pdf/NTE\% 20main\%20report\%20final.pdf, Accessed date: 20 January 2018.

European Union, 2018. Something from nothing? Ensuring the safety of chemical mixtures. http://publications.jrc.ec.europa.eu/repository/bitstream/JRC111886 kjna29258enn.pdf, Accessed date: 27 July 2018.

Falas, P., Wick, A., Castronovo, S., Habermacher, J., Ternes, T.A., Joss, A., 2016. Tracing the limits of organic micropollutant removal in biological wastewater treatment. Water Res. 95, 240-249.

Fatta-Kassinos, D., Bester, K., Kümmerer, K. (Eds.), 2010. Xenobiotics in the Urban Water Cycle: Mass Flows, Environmental Processes, Mitigation and Treatment Strategies, first ed. Springer, Netherland.

Fatta-Kassinos, D., Vasquesz, M.I., Kümmerer, K., 2011. Transformation products of pharmaceuticals in surface waters and wastewater formed during photolysis and advanced oxidation processes - degradation, elucidation of byproducts and assessment of their biological potency. Chemosphere 85, 693-709.

Fatta-Kassinos, D., Dionysiou, D., Kümmerer, K. (Eds.), 2016. Wastewater Reuse and Current Challenges, first ed. Springer, Switzerland.

Frank, U., Taconelli, E., 2012. The Daschner Guide to In-Hospital Antibiotic Therapy: European Standards. second ed. Springer, Heidelberg.

Funke, J., Prasse, C., Ternes, T.A., 2016. Identification of transformation products of antiviral drugs formed during biological wastewater treatment and their occurrence in the urban water cycle. Water Res. 98, 75-83.

Garcia-Käufer, D., Haddad, T., Bergheim, M., Gminski, R., Gupta, P., Mathur, N., Kümmerer K., Mersch-Sundermann, V., 2012. Genotoxic effect of ciprofloxacin during photolytic decomposition monitored by the in vitro micronucleus test (MNvit) in HepG2 cells. Environ. Sci. Pollut. Res. 19, 1719-1727.

Greene, S.A., Pohanish, R.P. (Eds.), 2005. Sittig's Handbook of Pesticides and Agricultural Chemicals, first ed. William Andrew Publishing, Norwich.

Greener Industries, d. http://www.greenerindustry.org.uk/pages/atom/1atom_yield.htm, Accessed date: 20 January 2018.

Gulde, R., Meier, U., Schymanski, E.L., Kohler, H.P.E., Helbling, D.E., Derrer, S., Rentsch, D. Fenner, K., 2016. Systematic exploration of biotransformation reactions of aminecontaining micropollutants in activated sludge. Environ. Sci. Technol. 50, 2908-2920.

Gutowski, L., Olsson, O., Leder, C., Kümmerer, K., 2015. A comparative assessment of the transformation products of S-metolachlor and its commercial product Mercantor Gold ${ }^{\circledR}$ and their fate in the aquatic environment by employing a combination of experimental and in silico methods. Sci. Total Environ. 506-507, 369-379.

Haddad, T., Kümmerer, K., 2014. Characterization of photo-transformation products of the antibiotic drug Ciprofloxacin with liquid chromatography-tandem mass spectrometry in combination with accurate mass determination using an LTQ-Orbitrap. Chemosphere 115, 40-46.

Haddad, T., Baginska, E., Kümmerer, K., 2015. Transformation products of antibiotic and cytostatic drugs in the aquatic cycle that result from effluent treatment and abiotic/ biotic reactions in the environment: an increasing challenge calling for higher emphasis on measures at the beginning of the pipe. Water Res. 72, 75-126.

Haiß, A., Jordan, A., Westphal, J., Logunova, E., Gathergood, N., Kümmerer, K., 2016. On the way to greener ionic liquids: identification of a fully mineralizable phenylalanine based ionic liquid. Green Chem. 16, 4315-4572.

Hanigan, D., Thurman, E.M., Ferrer, I., Zhao, Y., Andrews, S., Zhang, J., Herckes, P., Westerhoff, P., 2015. Methadone contributes to n-nitrosodimethylamine formation in surface waters and wastewaters during chloramination. Environ. Sci. Technol. Lett. 2, 151-157.

Harris, C.A., Sumpter, J.P., 2015. Could the quality of published ecotoxicological research be better? Environ. Sci. Technol. 49, 9495-9496.

Hatje, V., Bruland, K.W., Flegal, A.R., 2016. Increases in anthropogenic gadolinium anomalies and rare earth element concentrations in San Francisco Bay over a 20 year record. Environ. Sci. Technol. 4159-4168.

He, X., de la Cruz, A.A., Hiskia, A., Kaloudis, T., O'Shea, K., Dionysiou, D.D., 2015. Destruction of microcystins (cyanotoxins) by UV-254 nm-based direct photolysis and advanced oxidation processes (AOPs): influence of variable amino acids on the degradation kinetics and reaction mechanisms. Water Res. 74, 227-238.

Heller, S.R., McNaught, A., Pletnev, I., Stein, S., Tchekhovskoi, D., 2015. InChI, the IUPAC international chemical identifier. J. Cheminformatics 7, 23.

Hensen, B., Lange, J., Jackisch, N., Zieger, F., Olsson, O., Kümmerer, K., 2018. Entry of biocides and their transformation products into groundwater via urban stormwater infiltration systems. Water Res. 144, 13-423.

Herrmann, M., Menz, J., Olsson, O., Kümmerer, K., 2015. Identification of phototransformation products of the antiepileptic drug gabapentin: assessment of ready biodegradability and toxicity. Water Res. 85, 11-21.

Herrmann, M., Olsson, O., Fiehn, R., Herrel, M., Kümmerer, K., 2016a. The significance of different health institutions and their respective contributions of active pharmaceutical ingredients to wastewater. Environ. Int. 85, 61-76.

Herrmann, M., Menz, J., Gassmann, M., Olsson, O., Kümmerer, K., 2016b. The fate of the antipsychotic drug quetiapine in aquatic environments: an initials assessment of its transformation products. Environ. Pollut. 218, 66-76.

Illes, E., Szabó, E., Takács, E., Wojnárovits, L., Dombi, A., Gajda-Schrantz, K., 2014. Ketoprofen removal by $\mathrm{O}_{3}$ and $\mathrm{O}_{3} / \mathrm{UV}$ processes: kinetics, transformation products and ecotoxicity. Sci. Total Environ. 472, 178-184.

Isidori, M., Lavorgna, M., Nardelli, A., Parrella, A., Previtera, L., Rubino, M., 2005. Ecotoxicity of naproxen and its phototransformation products. Sci. Total Environ. 348, 93-101.

Jetten, M.S.M., Wagner, M., Fuerst, J., van Loosdrecht, M., Kuenen, G., Strous, M., 2001. Microbiology and application of the anaerobic ammonium oxidation ('anammox') process. Curr. Opin. Biotechnol. 12, 283-288.

Jia, S.T., Dai, X.H., Zhang, D., Dai, L.L., Wang, R.C., Zhao, J.F., 2013. Improved bioproduction of short-chain fatty acids from waste activated sludge by perennial ryegrass addition. Water Res. 47, 4576-4584.
Jones, O.H.A., Green, P.G., Voulvoulis, N., Lester, J., 2007. Questioning the excessive use of advanced treatment to remove organic micropollutants from wastewater. Environ. Sci. Technol. 41, 5085-5089.

Khaleel, N.D.H., Mahmoud, W.M.M., Olsson, O., Kümmerer, K., 2017. Initial fate assessment of teratogenic drug trimipramine and its photo-transformation products role of $\mathrm{pH}$, concentration and temperature. Water Res. 108, 197-211.

Kortenkamp, A., Faust, M., 2018. Regulate to reduce chemical mixture risk. Science 361 (6399), 224-226.

Krug, H.F., 2014. Nanosafety research - are we on the right track? Angew. Chem. Intern. 53, 12304-12319.

Kulaksız, S., Bau, M., 2011. Rare earth elements in the Rhine river, Germany: first case of anthropogenic lanthanum as a dissolved microcontaminant in the hydrosphere. Environ. Int. 37, 973-979.

Kümmerer, K., 1996. The ecological impact of time. Time Soc. 5, 209-235.

Kümmerer, K., 2007. Sustainable from the very beginning: rational design of molecules by life cycle engineering as an important approach for green pharmacy and green chemistry. Green Chem. 9, 899-907.

Kümmerer, K., 2010. Pharmaceuticals in the environment. Annu. Rev. Environ. Resour. 35, 57-75.

Kümmerer, K., 2017. Sustainable chemistry: a future guiding principle. Angew. Chem. Int Ed. 56, 16420-16421.

Kümmerer, K., Clark, J., 2016. Green and sustainable chemistry. In: Heinrichs, H., Mertens, P., Michelsen, G., Wieck, A. (Eds.), Sustainability Science - an Introduction. Springer, Dordrecht, Heidelberg, New York, London, pp. 43-60.

Kümmerer, K., Helmers, E., 2000. Hospital effluents as a source of gadolinium in the aquatic environment. Environ. Sci. Technol. 34, 573-577.

Kümmerer, K., Hempel, M. (Eds.), 2010. Green and Sustainable Pharmacy. Springer Heidelberg.

Kümmerer, K., Menz, J., Schubert, T., Thielemans, W., 2011. Biodegradability of organic nanoparticles in the aqueous environment. Chemosphere 82, 1387-1392.

Kümmerer, K., Dionysiou, D.D., Olsson, O., Fatta-Kassinos, D., 2018. A path to clean water Science 361 (6399), 222-224.

Kwon, M., Kim, S., Yoon, Y., Jung, Y., Hwang, T.M., Lee, J., Kang, J.W., 2015. Comparative evaluation of ibuprofen removal by $\mathrm{UV} / \mathrm{H}_{2} \mathrm{O}_{2}$ and $\mathrm{UV} / \mathrm{S}_{2} \mathrm{O}_{8}^{2-}$ processes for wastewater treatment. J. Chem. Eng. 269, 379-390.

Lambropoulou, D.A., Nollet, L.M.L. (Eds.), 2014. Transformation Products of Emerging Contaminants in the Environment: Analysis, Processes, Occurrence, Effects and Risks, first ed. Wiley, UK.

Längin, A., Schuster, A., Kümmerer, K., 2008. Chemicals in the environment - the need for a clear nomenclature: parent compounds, metabolites, transformation products and their elimination. Clean - Soil, Air, Water 36, 349-350.

Längin, A., Alexy, R., König, A., Kümmerer, K., 2009. Deactivation and transformation products in biodegradability testing of ß-lactams amoxicillin and piperacillin. Chemosphere 75, 347-354.

Leder, C., Rastogi, T., Kümmerer, K., 2015. Putting benign by design into practice-novel concepts for green and sustainable pharmacy: designing green drug derivatives by non-targeted synthesis and screening for biodegradability. Sustain. Chem. Pharm. 2, 31-36.

Li, S.W., Lin, A.Y.C., 2015. Increased acute toxicity to fish caused by pharmaceuticals in hospital effluents in a pharmaceutical mixture and after solar irradiation. Chemosphere 139, 190-196.

Li, Y., Niu, J., Wang, W., 2011. Photolysis of enrofloxacin in aqueous systems under simulated sunlight irradiation: kinetics, mechanism and toxicity of photolysis products. Chemosphere 85, 892-897.

Li, W., Gao, L., Shi, Y., Wang, Y., Liu, J., Cai, Y., 2015a. Spatial distribution, temporal variation and risks of parabens and their chlorinated derivatives in urban surface water in Beijing, China. Sci. Total Environ. 539, 262-270.

Li, W., Shi, Y., Gao, L., Liu, J., Cai, Y., 2015b. Occurrence, fate and risk assessment of parabens and their chlorinated derivatives in an advanced wastewater treatment plant. J. Hazard. Mater. 300, 29-38.

López-Serna, R., Jurado, A., Vázquez-Suñé, E., Carrera, J., Petrović, M., Barceló, D., 2013. Occurrence of 95 pharmaceuticals and transformation products in urban groundwaters underlying the metropolis of Barcelona, Spain. Environ. Pollut. 174, 305-315.

Lüddeke, F., Heß, S., Gallert, C., Winter, J., Guede, H., Loeffler, H., 2015. Removal of total and antibiotic resistant bacteria in advanced wastewater treatment by ozonation in combination with different filtering techniques. Water Res. 69, 243-251.

Luo, J.Y., Feng, L.Y., Chen, Y.G., Li, X., Chen, H., Xiao, N.D., Wang, D.B., 2014. Stimulating short-chain fatty acids production from waste activated sludge by nano zero-valent iron. J. Biotechnol. 187, 98-105.

MacLeod, M., Breitholtz, M., Cousins, I.T., de Wit, A.C., Persson, L.M., Rudén, C., McLachlan, M.S., 2014. Identifying chemicals that are planetary boundary threats. Environ. Sci. Technol. 48, 11057-11063.

Magdeburg, A., Stalter, D., Schlüsener, M., Ternes, T., Oehlmann, J., 2014. Evaluating the efficiency of advanced wastewater treatment: target analysis of organic contaminants and (geno-)toxicity assessment tell a different story. Water Res. 50, 35-47.

Maimon, A., Gross, A., 2018. Greywater: limitations and perspective. Curr. Opin. Environ. Sci. Health 2, 1-6.

Maimon, A., Friedler, E., Gross, A., 2014. Parameters affecting greywater quality and its safety for reuse. Sci. Total Environ. 487, 20-25.

Majewsky, M., Glauner, T., Horn, H., 2015. Systematic suspect screening and identification of sulfonamide antibiotic transformation products in the aquatic environment. Anal Bioanal. Chem. 407, 5707-5717.

Margot, J., Kienle, C., Magnet, A., Weil, M., Rossi, L., de Alencastro, L.F., Abegglen, C., Thonney, D., Chèvre, N., Schärer, M., Barry, D.A., 2013. Treatment of micropollutants in municipal wastewater: ozone or powdered activated carbon? Sci. Total Environ. $461-462$. 
Marti, E.J., Pisarenko, A.N., Peller, J.R., Dickenson, E.R.V., 2015. N-nitrosodimethylamine (NDMA) formation from the ozonation of model compounds. Water Res. 72, 262-270.

Martino, C., Bonaventura, R., Byrne, M., Roccheri, M., Matranga, V., 2017. Effects of exposure to gadolinium on the development of geographically and phylogenetically distant sea urchins species. Mar. Environ. Res. 128, 98-106.

Matsushita, T., Hashizuka, M., Kuriyama, T., Matsui, Y., Shirasaki, N., 2016. Use of orbitrapMS/MS and QSAR analyses to estimate mutagenic transformation products of iopamidol generated during ozonation and chlorination. Chemosphere 148, 233-240.

Menz, J., Toolaram, A.P., Rastogi, T., Leder, C., Olsson, O., Kümmerer, K., Schneider, M. 2017. Transformation products in the water cycle and the unsolved problem of their proactive assessment: a combined in vitro/in silico approach. Environ. Int. 98 $171-180$

Michael-Kordatou, I., Andreou, R., Iacovou, M., Frontistis, Z., Hapeshi, E., Michael, C., FattaKassinos, D., 2015. On the capacity of ozonation to remove antimicrobial compounds, resistant bacteria and toxicity from urban wastewater effluents. J. Hazard. Mater. 323 (A), 414-425.

Mitch, W.A., Sedlak, D.L., 2002. Formation of N-nitrosodimethylamine (NDMA) from dimethylamine during chlorination. Environ. Sci. Technol. 36, 588-595.

Möller, P., Dulski, P., Bau, M., Knappe, A., Pekdeger, A., Sommer-von Jarmersted, C., 2000. Anthropogenic gadolinium as a conservative tracer in hydrology. J. Geochem. Explor. 69-70, 409-414.

Mondala, A.H., Hernandez, R., French, T., McFarland, L., Domingo, J.W.S., Meckes, M., Ryu, H., Iker, B., 2012. Enhanced lipid and biodiesel production from glucose-fed activated sludge: kinetics and microbial community analysis. AICHE J. 58, 1279-1290.

Moreira, N.F.F., Sousa, J.M., Macedo, G., Ribeiro, A.R., Barreiros, L., Pedrosa, M., Faria, J.L. Pereira, M.F.R., Castro-Silva, S., Segundo, M.A., Manaia, C.M., 2016. Photocatalytic ozonation of urban wastewater and surface water using immobilized $\mathrm{TiO}_{2}$ with LEDs: micropollutants, antibiotic resistance genes and estrogenic activity. Water Res. 94, 10-22.

Mosby, 2016. Mosby's Medical Dictionary. 10th ed. Elsevier, Saint Lois.

Murphy, F., Ewins, C., Carbonnier, F., Quinn, B., 2016. Wastewater treatment works (WwTW) as a source of microplastics in the aquatic environment. Environ. Sci. Technol. 50, 5800-5808.

Nasuhoglu, D., Isazadeh, S., Westlund, P., Neamatallah, S., Yargeau, V., 2018. Chemical, microbial and toxicological assessment of wastewater treatment plant effluents during disinfection by ozonation. Chem. Eng. J. 346, 466-476.

Nödler, K., Hillebrand, O., Idzik, K., Strathmann, M., Schiperski, F., Zirlewagen, J., Licha, T. 2013. Occurrence and fate of the angiotensin II receptor antagonist transformation product valsartan acid in the water cycle - a comparative study with selected ßbeckers and the persistent anthropogenic wastewater indicators carbamazepine and acesulfame. Water Res. 47, 6650-6659.

Oaks, L.J., Gilbert, M., Virani, Z.M., Watson, R.T., Meteyer, C.U., Rideout, B.A., Shivaprasad, H.L., Ahmed, S., C.M.J.I., Arshad, M., Mahmood, S., Ali, Khan A.A., 2004. Diclofenac residues as the cause of vulture population decline in Pakistan. Nature 427, 630-633.

OECD, 2012. OECD Environmental Outlook to 2050. OECD Publishing https://doi.org/ 10.1787/9789264122246-en (accessed 22.2.2017).

Oller, I., Malato, S., Sánchez-Pérez, J.A., 2011. Combination of advanced oxidation processes and biological treatments for wastewater decontamination-a review. Sci. Total Environ. 409 (20), 4141-4166.

Ooi, G.T.H., Tang K. Chhetri, R.K. Kaarsholm, K.M.S., Sundmark, K, Kragelund, C., Litty, K. Christensen, A. Lindholst, S., Sund, C., Christensson, M., Bester, K., Andersen, H.R. 2018. Biological removal of pharmaceuticals from hospital wastewater in a pilotscale staged moving bed biofilm reactor (MBBR) utilising nitrifying and denitrifying processes. Bioresour. Technol. 267, 677-687.

Oron, G., Adel, M., Agmon, V., Friedler, E., Halperin, R., Leshem, E., et al., 2014. Greywater use in Israel and worldwide: standards and prospects. Water Res. 58, 92-101.

Paltiel, O., Fedorova, G., Tadmor, G., Kleinstern, G., Maor, Y., Chefetz, B., 2016. Human exposure to waste water-derived pharmaceuticals in fresh produce: a randomized controlled trial focusing on carbamazepine. Environ. Sci. Technol. 50, 4476-4482 (11763).

Persson, L.M., Breitholtz, M., Cousins, I.T., de Wit, C.A., MacLeod, M., McLachlan, M.S., 2013. Confronting unknown planetary boundary threats from chemical pollution. Environ. Sci. Technol. 47, 12619-12622.

Postigo, C. Richardson, S.D. 2014. Transformation of pharmaceuticals during oxidation/ disinfection processes in drinking water treatment. J. Hazard. Mater. 279, 461-475.

Rastogi, T., Leder, C., Kümmerer, K., 2014. Designing green derivatives of $\beta$-blocker metoprolol: a tiered approach for green and sustainable pharmacy and chemistry Chemosphere 111, 493-499.

Rastogi, T., Leder, C., Kümmerer, K., 2015a. A sustainable chemistry solution to the presence of pharmaceuticals and chemicals in the aquatic environment - the example of re-designing B-blocker atenolol. RSC Adv. 5, 27-32.

Rastogi, T., Leder, C., Kümmerer, K., 2015b. Re-designing of existing pharmaceuticals for environmental biodegradability: a tiered approach with $\beta$-blocker propranolol as an example. Environ. Sci. Technol. 49, 11756-11763.

Rastogi, T., Mahmoud, W.M.M., Kümmerer, K., 2018. Human and veterinary drugs in the environment. Encycl. Anthropocene 5, 263-268.

Reemtsma, T., Berger, U., Arp, H.P.H., Gallard, H., Knepper, T.P., Neumann, M., Quintana, J.B., Voogt, P.D., 2016. Mind the gap: persistent and mobile organic compounds water contaminants that slip through. Environ. Sci. Technol. 50, 10308-10315.

Renn, O., Keil, F., 2009. What is systemic about systemic risks? (Was ist das systemische an systemischen Risiken?) Gaia 18, 97-99.

Rieger, P.-G., Meier, H.-M., Gerle, M., Vogt, U., Groth, T., Knackmuss, H.-J., 2002. Xenobiotics in the environment: present and future strategies to obviate the problem of biological persistence. J. Biotechnol. 94, 101-123.

Rockström, J., Steffen, W., Noone, K., Persson, A., Chapin, S.F., Lambin, E.F., Lenton, T.M., Scheffer, M., Folke, C., Schellnhuber, H.J., Nykvist, B., de Wit, C.A., Hughes, T., van der Leeuw, S., Rodhe, H., Sörlin, S., Snyder, P.K., Costanza, R., Svedin, U., Falkenmark, M., Karlberg, L., Corell, R.W., Fabry, V.J., Hansen, J., Walker, B., Liverman, D., Richardson, K., Crutzen, P., Foley, J.A., 2009. A safe operating space for humanity. Nature 461, 472-475.

Rozas, O., Vidal, C., Baeza, C., Jardim, W.F., Rossner, A., Mansilla, H.D., 2016. Organic micropollutants (OMPs) in natural waters: oxidation by UV/H2O2 treatment and toxicity assessment. Water Res. 98, 109-118.

Rücker, C., Kümmerer, K., 2015. Environmental chemistry of organosiloxanes. Chem. Rev. $115,466-524$.

Schmidt, C.K., Brauch, H.J., 2008. N, N-dimethylsulfamide as precursor for Nnitrosodimethylamine (NDMA) formation upon ozonation and its fate during drinking water treatment. Environ. Sci. Technol. 42, 6340-6346.

Schwarzenbach, R.P., Escher, B.I., Fenner, K., Hofstetter, T.B., Johnson, C.A., von Gunten, U., Wehrli, B., 2006. The challenge of micropollutants in aquatic systems. Science 313, 1072-1077.

Shannon, M.A., Bohn, P.W., Elimelech, M., Georgiadis, J.G., Mariñas, B.J., Mayes, A.M., 2008. Science and technology for water purification in the coming decades. Nature 452, 301-310.

Siemers, A.K., Mänz, J.S., Palm, W.-U., Ruck, W.K.L., 2015. Development and application of a simultaneous SPE-method for polycyclic aromatic hydrocarbons (PAHs), alkylated PAHs, heterocyclic PAHs (NSO-HET) and phenols in aqueous samples from German rivers and the North Sea. Chemosphere 122, 105-114.

Silva, E., Rajapakse, N., Kortenkamp, A., 2002. Something from "nothing" - eight weak estrogenic chemicals combined at concentrations below noecs produce significant mixture effects. Environ. Sci. Technol. 36, 1751-1756.

Song, C., Wang, L., Ren, J., Lv, B., Sun, Z., Yan, J., Li, X., Liu, J., 2016. Comparative study of diethyl phthalate degradation by $\mathrm{UV} / \mathrm{H}_{2} \mathrm{O}_{2}$ and $\mathrm{UV} / \mathrm{TiO}_{2}$ : kinetics, mechanism, and effects of operational parameters. Environ. Sci. Pollut. Res. 23, 2640-2650.

Stahl, T., Falk, S., Brunn, H., 2017. Anthropogene Per- und Polyfluoralkylsubstanzen (PFAS) in der Umwelt - eine "Never-Ending Story?". Mitt. Umweltchem. Ökotox. 23, 64-68.

Steffen, W., Richardson, K., Rockström, J., Cornell, S.E., Fetzer, I., Bennett, E.M., Biggs, R., Carpenter, S.R., de Vries, W., de Wit, C.A., Folke, C., Gerten, D., Heinke, J., Mace, G.M., Persson, L.M., Ramanathan, V., Reyers, R., Sörlin, S., 2015. Planetary boundaries: guiding human development on a changing planet. Science 347, 1259855

Straub, J.O. 2016. Reduction in the environmental exposure of pharmaceuticals through diagnostics, Personalised Healthcare and other approaches. A mini review and discussion paper. Sustain. Chem. Pharm. 3, 1-7

Streek, M., Achilles, F., Bauer, M., Hempel, M., Köhl, P., Kümmerer, K., Löwer, B., Pinnow, P., Sauerteig, S., Schuster, A., Strecker, S., Scholze, K., 2011. Chemikalien-leasing effiziente und nachhaltige Krankenhaushygiene (Chemical leasing - efficient and sustainable hospital hygiene). Final Report https://www.dbu.de/OPAC/ab/DBUAbschlussbericht-AZ-26035.pdf, Accessed date: 20 February 2017.

Su, T., Deng, H., Benskin, J.P., Radke, M., 2016. Biodegradation of sulfamethoxazole phototransformation products in a water/sediment test. Chemosphere 148, 518-525.

TEGEWA, 2018. http://www.tegewa.de/en/publications/international-textile-auxiliariesbuyers-guide-tag.html, Accessed date: 26 July 2018

Ter Laak, T., Tolkamp, H., Hofman, J., 2013. Geneesmiddelen in de Watercyclus in Limburg. KWR Report, 2013.011, Nieuwegein. http://www.kwrwater.nl/uploadedFiles/Website_ KWR/RC-map/NieuWs/KWR\%202013.011\%20Rapport\%20Geneesmiddelen\%20in\%20de \%20Watercyclus\%20in\%20Limburg\%20\%20Fase1.pdf, Accessed date: 17 March 2018.

Toolaram, A.P., Kümmerer, K., Schneider, M., 2014. Environmental risk assessment of anticancer drugs and their transformation products: a focus on their genotoxicity characterization-state of knowledge and short comings. Mutat. Res. Rev. Mutat. Res. 760, 18-35

Tootchi, L., Seth, R., Tabe, S., Yang, P., 2013. Transformation products of pharmaceutically active compounds during drinking water ozonation. Water Sci. Technol. Water Supply $13,1576-1582$.

Toropov, A.A., Toropova, A.P., 2018. Improved model for biodegradability of organic compounds: the correlation contributions of rings. In: Bidoia, E.D., Montagnolli, R.N. (Eds.), Toxicity and Biodegradation Testing Methods in Pharmacology and Toxicology. Springer, pp. 147-183.

Trautwein, C., Kümmerer, K., Metzger, J.W., 2008. Aerobic biodegradability of the calcium channel antagonist verapamil and identification of a microbial dead-end transformation product studied by LC-MS/MS. Chemosphere 72, 442-450.

Trautwein, C., Berset, J.D., Wolschke, H., Kümmerer, K., 2014. Occurrence of the antidiabetic drug metformin and its ultimate transformation product Guanylurea in several compartments of the aquatic cycle. Environ. Int 70, 203-212.

Triebskorn, R., Casper, H., Heyd, A., Eikemper, R., Köhler, H.R., 2004. Toxic effects of the nonsteroidal anti-inflammatory drug diclofenac. Part ii: cytological effects in liver, kidney, gills and intestine of rainbow trout (Oncorhynchus mykiss). Aquat Toxicol. 68, 151-166.

Triebskorn, R., Casper, H., Scheil, V., Schwaiger, J., 2007. Ultrastructural effects of pharmaceuticals (carbamazepine, clofibric acid, metoprolol, diclofenac) in rainbow trout (Oncorhynchus mykiss) and common carp (Cyprinus carpio). Anal. Bioanal. Chem. 387, 1405-1416.

Tshala-Katumbay, D., Mwanza, J.C., Rohlman, D.S., Maestre, G., Oriá, R.B., 2015. A global perspective on the influence of environmental exposures on the nervous system. Nature 527, 187-192.

Umweltbundesamt (UBA), 2018. https://www.umweltbundesamt.de/daten/ chemikalien\#strap1, Accessed date: 10 February 2018.

UN 2015: United Nations Development Programme, Sustainable Development Goals, et al. 2015. http://www.undp.org/content/undp/en/home/mdgoverview/post-2015development-agenda/goal-6.html, Accessed date: 20 February 2018.

United Nations Environment Programme (UNEP), 2013. Global chemicals outlook - towards sound management of chemicals. https://sustainabledevelopment.un.org/content/documents/1966Global\%20Chemical.pdf, Accessed date: 10 March 2018. 
United Nations Environmental Programme (UNEP), United Nations Environment Assembly of the United Nations Environment Programme, 2016. http://web.unep. org/unea/list-resolutions-adopted-unea-2, Accessed date: 20 January 2018.

United Nations Industrial Development Organization (UNIDO), 2016. Global Promotion and Implementation of Chemical Leasing Business Models in Industry. http://www. chemicalleasing.org/docs/20160310_10\%20Years\%20Chemical\%20Leasing\%20Report \%20and\%20Strategy\%200utlook_FV.pdf, Accessed date: 21 April 2017.

United Nations Water (UN Water), 2017. Wastewater. The untapped resource report, 2017, The United Nations World Water Development Report 2017. http://www. unesco.org/new/en/natural-sciences/environment/water/wwap/wwdr/2017-wastewater-the-untapped-resource/, Accessed date: 20 July 2018.

United States EPA, 2017. https://www.epa.gov/saferchoice/history-safer-choice-and-design-environment, Accessed date: 20 January 2018.

Van Wezel, A., Caris, I., Kools, S.A.E., 2016. Release of primary microplastics from consumer products to wastewater in the Netherlands. Environ. Toxicol. Chem. 35, 1627-1631.

Vasquez, M.I., Garcia-Käufer, M., Hapeshi, E., Menz, J., Kostarelos, K., Fatta-Kassinos, D., Kümmerer, K., 2013. Chronic ecotoxic effects to pseudomonas putida and vibrio fischeri, and cytostatic and genotoxic effects to the hepatoma cell line (HepG2) of ofloxacin photo(cata)lytically treated solutions. Sci. Total Environ. 450-451.

Verstraete, W., Vlaeminck, S.E., 2011. ZeroWasteWater: short-cycling of wastewater resources for sustainable cities of the future. Int J Sust Dev World 18, 253-264.

Vincze, K., Scheil, V., Kuch, B., Köhler, H.R., Triebskorn, R., 2015. Impact of wastewater on fish health: a case study at the Neckar River (Southern Germany) using biomarkers in caged brown trout as assessment tools. Environ. Sci. Pollut. Res. 22, 11822-11839.

Wagner, V., 2008. http://www.dwa.de/portale/sanierungstage/sanierungstage.nsf/ C125724A004A8288/0BD7F7A838A62618C125768600378611/\$FILE/T1_R6_Wagner.pdf, Accessed date: 16 January 2018.
Waters, C.N., Zalasiewicz, J., Summerhayes, C., et al., 2016. The Anthropocene is functionally and stratigraphically distinct from the Holocene. Science 351 (6269).

Weil, E.D., Levchik, S.V., 2015. Flame Retardants for Plastics and Textiles: Industrial Applications. Second Ed. Hanser, München.

Weiser, A., Lang, D.J., Kümmerer, K., 2017. Putting sustainable chemistry and resource use into context: the role of temporal diversity. Sustain. Chem. Pharm. 5, 105-114.

Wendel, F.M., Ternes, T.A., Richardson, S.D., Duirk, S.E., Pals, J.A., Wagner, E.D., Plewa, M.J. 2016. Comparative toxicity of high-molecular weight iopamidol disinfection byproducts. Environ. Sci. Technol. Lett. 3, 81-84.

Wieck, S., Olsson, O., Kümmerer, K., 2016. Possible underestimations of risks for the environment due to unregulated emissions of biocides from households to wastewater Environ. Int. 94, 695-705.

Wieck, S., Olsson, O., Kümmerer, K., 2018. Consumers' perceptions of biocidal products in households. Int. J. Hyg. Environ. Health 221, 260-268.

Wirz, K.C., Studer, M., Straub, J.O., 2015. Environmental risk assessment for excipients from galenical pharmaceutical production in wastewater and receiving water. Sustain. Chem. Pharm. 1, 28-35.

Worch, E., 2012. Adsorption Technology in Water Treatment: Fundamentals, Processes, and Modeling. De Gruyter, Berlin.

Zeng, T., Mitch, W.A., 2015. Contribution of N-nitrosamines and their precursors to domestic sewage by greywaters and blackwaters. Environ. Sci. Technol. 49, 13158-13167.

Zhang, S., Wu, C., Zhou, Y., Wang, Y., He, X., 2018. Effect of wastewater particles on catalytic ozonation in the advanced treatment of petrochemical secondary effluent Chem. Eng. J. 345, 280-289. 